\title{
Role of DNA Methylation in the Nucleus Accumbens in Incubation of Cocaine Craving
}

\author{
Renaud Massart, ${ }^{1 *}$ Royi Barnea, $, 2,3 *$ Yahav Dikshtein, ${ }^{2,3 *}$ Matthew Suderman, ${ }^{1,4}$ Oren Meir, ${ }^{2,3}$ Michael Hallett, ${ }^{4}$ \\ Pamela Kennedy, ${ }^{5}$ Eric J. Nestler, ${ }^{5}$ Moshe Szyf, ${ }^{1,6}$ and Gal Yadid ${ }^{2,3}$ \\ ${ }^{1}$ Department of Pharmacology \& Therapeutics, McGill University, Montreal, Quebec H3G 1Y6, Canada, ${ }^{2}$ Leslie and Susan Gonda (Goldschmied) \\ Multidisciplinary Brain Research Center, Bar-Ilan University, Ramat Gan 52900, Israel, ${ }^{3}$ Mina and Everard Goodman Faculty of Life Sciences, Bar-Ilan \\ University, Ramat-Gan 52900, Israel, ${ }^{4}$ McGill Centre for Bioinformatics, McGill University, Montreal, Quebec H3G 0B1, Canada, ${ }^{5}$ Fishberg Department of \\ Neuroscience and Friedman Brain Institute, Mount Sinai School of Medicine, New York, New York 10029, and ${ }^{6}$ Sackler Program for Epigenetics and \\ Psychobiology, McGill University, Montreal, Quebec H3G 0B1, Canada
}

One of the major challenges of cocaine addiction is the high rate of relapse to drug use after periods of withdrawal. During the first few weeks of withdrawal, cue-induced cocaine craving intensifies, or "incubates," and persists over extended periods of time. Although several brain regions and molecular mechanisms were found to be involved in this process, the underlying epigenetic mechanisms are still unknown. Herein, we used a rat model of incubation of cocaine craving, in which rats were trained to self-administer cocaine ( 0.75 $\mathrm{mg} / \mathrm{kg}, 6 \mathrm{~h} / \mathrm{d}, 10 \mathrm{~d}$ ), and cue-induced cocaine-seeking was examined in an extinction test after 1 or $30 \mathrm{~d}$ of withdrawal. We show that the withdrawal periods, as well as cue-induced cocaine seeking, are associated with broad, time-dependent enhancement of DNA methylation alterations in the nucleus accumbens (NAc). These gene methylation alterations were partly negatively correlated with gene expression changes. Furthermore, intra-NAc injections of a DNA methyltransferase inhibitor (RG108, $100 \mu \mathrm{M})$ abolished cue-induced cocaine seeking on day 30, an effect that persisted 1 month, whereas the methyl donor S-adenosylmethionine (500 $\mu \mathrm{M})$ had an opposite effect on cocaine seeking. We then targeted two proteins whose genes were demethylated by RG108-estrogen receptor 1 (ESR1) and cyclin-dependent kinase 5 (CDK5). Treatment with an intra-NAc injection of the ESR1 agonist propyl pyrazole triol (10 nM) or the CDK5 inhibitor roscovitine $(28 \mu \mathrm{M})$ on day 30 of withdrawal significantly decreased cue-induced cocaine seeking. These results demonstrate a role for NAc DNA methylation, and downstream targets of DNA demethylation, in incubation of cocaine craving.

Key words: cocaine addiction; DNA methylation; nucleus accumbens; incubation of cocaine craving

\section{Introduction}

Cocaine craving and relapse in humans can be triggered by acute exposure to drug-associated cues, even after long durations of abstinence (Hunt et al., 1971; Pickens et al., 2011). Thus, it has been postulated that cue-induced cocaine craving does not decay, but progressively intensifies, or "incubates," over the first few weeks of withdrawal and persists over extended periods of time (Gawin and Kleber, 1986). Recent evidence in humans has shown

Received July 23, 2014; revised March 2, 2015; accepted March 7, 2015.

Author contributions: R.M., Y.D., M. Szyf, and G.Y. designed research; R.M., R.B., Y.D., O.M., and P.K. performed research; M.H. and E.J.N. contributed unpublished reagents/analytic tools; R.M., R.B., M. Suderman, M. Szyf, and G.Y. analyzed data; R.M., R.B., M. Suderman, M. Szyf, and G.Y. wrote the paper.

This work was supported by Canadian Institute of Health Research Grant MOP-42411 to M. Szyf, Ministere du Developpement Economique de I'Innovation et de l'Exportation program of the government of Quebec, and the Israel Anti-Drug Authority to G.Y. Microarray data were deposited in NCBI's Gene Expression Omnibus. They are accessible through GEO Series accession number GSE66350 (http://www.ncbi.nlm.nih.gov/geo/query/acc. cgi?acc $=$ GSE66350). We wish to thank Dr. Tamar Sadan for critically reading and editing the manuscript.

The authors declare no competing financial interests.

${ }^{*}$ R.M., R.B., and Y.D. contributed equally to this work.

Correspondence should be addressed to either of the following: Dr. Moshe Szyf, Department of Pharmacology and Therapeutics, McGill University, 3655 Promonade Sir William Osler, Montreal, Quebec H3G Y6, Canada, E-mail: moshe.szyf@mcgill.ca; or Gal Yadid, Mina and Everard Goodman Faculty of Life Sciences, Bar-Ilan University, RamatGan 52900, Israel. E-mail: yadidg@gmail.comgmail.com.

DOI:10.1523/JNEUROSCI.3053-14.2015

Copyright $\odot 2015$ the authors $\quad 0270-6474 / 15 / 358042-17 \$ 15.00 / 0$ time-dependent increases in cue-induced nicotine (Bedi et al., 2011), alcohol (Li et al., 2014), and methamphetamine (Wang et al., 2013) craving during withdrawal. An analogous phenomenon of incubation of cocaine craving has been identified in rats (Grimm et al., 2001; Pickens et al., 2011). Previous studies have revealed several mesolimbic brain regions and molecular mechanisms that play a role in this phenomenon. These include BDNF and GDNF in the ventral tegmental area (Grimm et al., 2003; Lu et al., 2009), ERK and glutamate in the central amygdala (Lu et al., 2005; Lu et al., 2007), and ERK and GABA in the ventral mPFC (Koya et al., 2009). The nucleus accumbens (NAc), a central reward-related region in which pathways that control cocaine seeking converge, was also shown to have a crucial role in incubation of cocaine craving (Pickens et al., 2011). Factors associated with incubation of cocaine craving in this region include $\beta$-endorphin and its $\delta$ receptor (Dikshtein et al., 2013), BDNF, and its phosphorylated TrkB receptor (Grimm et al., 2003, Li et al., 2013), calcium-permeable GluA2-lacking AMPA receptors (Conrad et al., 2008; Wolf and Tseng, 2012; Scheyer et al., 2014), and mGLuR1 (Loweth et al., 2014), as well as silent synapse-based reorganization of the amygdala-to-NAc projection (Lee et al., 2013). However, the epigenetic mechanisms that underlie incubation of cocaine craving are still unknown. 
DNA methylation is a covalent modification of DNA that confers upon DNA different cellular identities during embryogenesis (Razin and Riggs, 1980). DNA methylation in promoters and regulatory regions silences gene expression either by interfering with the binding of transcription factors (Comb and Goodman, 1990) or by attracting methylated DNA-binding proteins and chromatin-modifying proteins leading to inactive chromatin structure (Nan et al., 1998). Recent data suggest that, in addition to its role in cellular differentiation, DNA methylation can alter gene expression programs in response to experience (Meaney and Szyf, 2005; Klengel et al., 2013) and is involved in memory formation and synaptic plasticity (LaPlant et al., 2010; Zovkic et al., 2013). Epigenetic mechanisms may be a key molecular basis of enduring changes in brain plasticity related to addiction (Anier et al., 2010; Maze et al., 2010; Robison and Nestler, 2011; Nielsen et al., 2012; Tian et al., 2012). However, the most studied epigenetic alterations that were associated with the effects of cocaine relate to post-transcriptional histone modifications of several candidate promoters (Renthal et al., 2007, 2009; LaPlant et al., 2010; Maze et al., 2010), with only a few studies focusing on DNA methylation changes (Anier et al., 2010; Nielsen et al., 2012; Tian et al., 2012; Lattal and Wood, 2013). Recently, DNA methylation in the VTA was shown to be required for formation of stimulusreward associations (Day et al., 2013). Yet, to our knowledge, no study has hitherto explored the possible involvement of DNA methylation, and particularly that occurring in the NAc, in the complex mechanisms underlying incubation of cocaine craving.

In the present study, we determined cue-induced cocaine seeking in extinction tests after 1 or 30 withdrawal days, followed by analysis of DNA methylation profiles and correlating gene expression changes in the NAc of rats, combining unbiased whole-genome and candidate gene approaches. We also examined "incubated" (high) cue-induced cocaine-seeking behavior following intra-NAc injection of a DNA methyltransferase (DNMT) inhibitor (RG108), a methyl donor, or pharmacological agents targeting proteins whose genes were demethylated by RG108.

\section{Materials and Methods}

For detailed experimental design, see Figure 1.

Animals. Male Sprague Dawley rats (Harlan) weighing 250-350 g were maintained on a $12 \mathrm{~h}$ light/12 h dark reversed cycle, with food and water available ad libitum. Rats were housed 2 per cage with a metal divider between them. Experiments were conducted during the dark cycle. All experimental procedures were approved by the University Animal Care and Use Committees and were performed in accordance with National Institutes of Health guidelines.

Guide cannula implantation. Rats were anesthetized with xylazine and ketamine $(10 \mathrm{mg} / \mathrm{kg}$ and $100 \mathrm{mg} / \mathrm{kg}$, respectively). A 20-gauge guide cannula was then unilaterally implanted into the NAc (anteroposterior, $1.4 \mathrm{~mm}$; mediolateral, $1.2 \mathrm{~mm}$ to bregma; and dorsoventral, $-6.6 \mathrm{~mm}$ ) of rats with the aid of a stereotactic device (David Kopf Instruments). For sample image of guide cannula placement in the NAc, see Figure $1 D$.

Jugular vein catheterization. Immediately after cannula implantation, rats were implanted with intravenous Silastic catheters (ID $0.55 \mathrm{~mm}, \mathrm{OD}$ $0.94 \mathrm{~mm}$, Dow Corning) into the right jugular vein. The catheter was secured to the vein with silk sutures and was passed subcutaneously to the top of the skull, where it exited into a connector (a modified 22-gauge cannula; Plastics One) mounted to the skull with MX-80 screws (Small Parts) and dental cement (Yates and Bird).

Cocaine self-administration. Rats were trained to self-administer cocaine for $6 \mathrm{~h}$ per day, over $10 \mathrm{~d}$. The self-administration chambers (Med Associates) had two levers: one active and one inactive. An active lever press generated a cocaine infusion $(0.75 \mathrm{mg} / \mathrm{kg}, 0.13 \mathrm{ml}, 5 \mathrm{~s} /$ infusion; cocaine obtained from the National Institutes on Drug Abuse) through the intravenous catheter, and also activated a light located above the lever, which was lit for $40 \mathrm{~s}$. Active lever presses during the last $35 \mathrm{~s}$ of the light cue did not result in additional cocaine infusions. Presses on the inactive lever did not activate the infusion pump and light. Control rats were subjected to saline self-administration training under the same conditions. The number of active lever responses, infusions, and inactive lever responses were recorded for both treatment and control groups. Rats were returned to their home cages at the end of the daily sessions.

Cocaine withdrawal (forced abstinence). After the 10 day period of selfadministration training sessions, rats were subjected to either a 1 day period of withdrawal (for cocaine-trained and saline-trained rats) or 30 day period of withdrawal (cocaine-trained rats). During the withdrawal periods, rats were left in their home cages and handled 3 times a week.

For examining DNA methylation alterations after the 1 day or 30 day withdrawal periods, rats from each group $(n=8)$ were killed, their brains removed, and tissue punches were taken for NAc isolation and further epigenetic analysis (detailed below). The remaining cocaine-trained rats ( $n=9$ per group) were subjected to an extinction test for assessment of cue-induced cocaine-seeking behavior (on either day 1 or day 30 of withdrawal).

Extinction test. Rats were placed in the self-administration chambers, and only the contingent light cue appeared during active lever presses, without cocaine reinforcement. Cocaine-seeking behavior was assessed for $60 \mathrm{~min}$

For examining DNA methylation alterations, brains were removed $1 \mathrm{~h}$ after completion of the session, and the NAc was isolated for further epigenetic analysis (detailed below).

Modulation of NAc DNA methylation. Another group of rats were trained to self-administer cocaine $(0.75 \mathrm{mg} / \mathrm{kg}, 0.13 \mathrm{ml}, 5$ s/infusion, 6 $\mathrm{h} / \mathrm{d}$ for $10 \mathrm{~d}$ ) and then subjected to $30 \mathrm{~d}$ of withdrawal. On day 29 and on day 30 of withdrawal, rats received an intra-NAc injection of either the DNMT inhibitor RG108 (100 $\mu \mathrm{M}$; Sigma; $n=16$ ) (LaPlant et al., 2010) or the methyl donor S-adenosylmethionine (SAM, Sigma; $500 \mu \mathrm{M} ; n=13$ ) (Shukeir et al., 2006). Control rats $(n=13)$ received intra-NAc injections of aCSF at the same time points.

The drugs were infused ( $5 \mathrm{~min}, 0.2 \mu \mathrm{l} / \mathrm{min}$ ) into the NAc via an injection cannula inserted into the guide cannula, and using an electronic syringe pump (CMA 400, CMA/Microdialysis). The injection cannula remained in place for $5 \mathrm{~min}$ after infusion to avoid reflux. On day 29, rats were returned to their home cage after infusions. On day 30, immediately $(<5 \mathrm{~min})$ after infusions, rats underwent an extinction test to assess cue-induced cocaine-seeking behavior.

Immediately after completion of the extinction test, part of the rats from all three groups either had brains removed for NAc epigenetic analysis (procedures and groups sizes detailed below) or returned to their home cages and underwent extinction testing again on day 60 ( $n=6$ for RG108-treated, $n=5$ for SAM-treated, $n=4$ for aCSF-treated rats) (see Fig. 1). The remainder of the RG108-treated and aCSF-treated groups underwent further behavioral assessments (elevated plus maze, open field, object recognition; procedures and group sizes detailed below).

Pharmacological modulation of downstream targets of DNA methylation inhibition. Another group of rats was trained to self-administer cocaine $(0.75 \mathrm{mg} / \mathrm{kg}, 0.13 \mathrm{ml}, 5 \mathrm{~s} /$ infusion, $6 \mathrm{~h} / \mathrm{d}$ for $10 \mathrm{~d})$ and then subjected to $30 \mathrm{~d}$ of withdrawal. On day 29 and on day 30, rats received intra-NAc injection of the estrogen receptor (ESR) agonist propyl pyrazole triol (PPT, Sigma; $10 \mathrm{~nm} ; n=6$ ), based on Sun et al. (1999) or the selective CDK inhibitor roscovitine (Sigma; $28 \mu \mathrm{M} ; n=6$ ), based on Meijer et al. (1997). Controls received intra-NAc aCSF $(n=4)$. The drugs were infused ( $5 \mathrm{~min}, 0.2 \mu \mathrm{l} / \mathrm{min}$ ) via the electronic syringe pump, and the injection cannula remained in place for $5 \mathrm{~min}$ after infusions. Immediately after drug infusions on day 30 , rats underwent an extinction test to assess cue-induced cocaine-seeking behavior.

Elevated plus maze. Immediately after the extinction test, rats that received an intra-NAc RG108 injection $(n=7)$ or aCSF $(n=6)$ were tested in the elevated plus maze. The plus maze consisted of two open arms, $50 \times 10 \mathrm{~cm}$, and two enclosed arms, $50 \times 10 \times 40 \mathrm{~cm}$ with an open roof, arranged such that the two arms of each type were opposite each other. The maze was elevated from the floor to a height of $70 \mathrm{~cm}$. The walls of the enclosed arms were made from black foam board, whereas 
the floors were made from white foam board. Rats were placed in the central area, facing a closed arm, and movements in the maze were monitored for $5 \mathrm{~min}$. After the test, the animal was returned its home cage and the apparatus was cleaned with $70 \%$ alcohol to remove odors.

Open field test. Physical performance was examined by monitoring locomotion in rats $1 \mathrm{~h}$ after the elevated plus maze test $(n=6$ for both RG108-injected and aCSF-injected rats). Rats were placed in an open field apparatus $(60 \times 60 \mathrm{~cm}$ with 30 -cm-high walls). Locomotor activity was measured for $10 \mathrm{~min}$. The locomotor test in the open field apparatus was also used as a habituation session for the object recognition test.

Object recognition test. One hour after testing locomotion, a training session for object recognition testing was conducted in the open field apparatus ( $n=6$ rats, for both RG108-injected and aCSF-injected groups). Objects (A1, A2) similar in texture, color patterning, and size (8 $\mathrm{cm}$ long and $8 \mathrm{~cm}$ high), but with distinctive shapes, were used. Each rat was placed for $5 \mathrm{~min}$ in the open field with two identical objects (A1 and A2) positioned in two adjacent corners, $10 \mathrm{~cm}$ from the walls. Long-term memory (LTM) was assessed $24 \mathrm{~h}$ after the training session, by analysis of the rat's exploration of the open field for $5 \mathrm{~min}$ in the presence of one familiar (A) and one novel object (B). "Exploration" was defined as sniffing or touching the object with the nose and/or forepaws. The exploratory preference for each object was calculated as the time $(\mathrm{t})$ spent in exploring that object, expressed as the percentage of total exploration time $\left[\left(\mathrm{t}_{\mathrm{A} 2} /\left(\mathrm{t}_{\mathrm{A} 1}+\mathrm{t}_{\mathrm{A} 2}\right) \times 100\right]\right.$. LTM recognition was evaluated as the time spent by the rat in exploring the novel object, expressed as a percentage of the total exploration time $\left[\mathrm{LTM}=\left(\mathrm{t}_{\mathrm{B}} /\left(\mathrm{t}_{\mathrm{Al}}+\mathrm{t}_{\mathrm{B}}\right) \times 100\right]\right.$. Between trials, the objects were washed with $10 \%$ ethanol solution. Rats were removed from the open field and returned to their home cages at the termination of each trial.

Sucrose self-administration. Rats were placed in operant conditioning chambers (Med Associates) for daily $3 \mathrm{~h}$ sessions, over $10 \mathrm{~d}$, during their dark cycle, in the self-administration chambers with active and inactive levers. An active lever press delivered sucrose ( $10 \%$ sucrose solution; 0.13 $\mathrm{ml} /$ infusion) into a liquid drop receptacle for oral consumption. A light located above the active lever was lit during the sucrose infusion periods that lasted $5 \mathrm{~s}$ and remained lit for $15 \mathrm{~s}$ beyond the infusion period. Throughout these $15 \mathrm{~s}$ intervals, active lever presses were recorded, but no additional sucrose reinforcement was provided. Presses on the inactive lever were recorded, but they did not activate the infusion pump and light. Rats were returned to their home cages at the end of the daily sessions. Rats were then subjected to a 21 day period of withdrawal. On day 21, rats received intra-NAc injections of aCSF $(n=6)$, PPT (10 nм, $n=6$ ), or roscovitine ( $28 \mu \mathrm{M}, n=7)$ and cue-induced sucrose seeking was examined in an extinction test: the rats were placed in the selfadministration cages with the contingent light cue appearing during active lever presses, but no sucrose delivery. The number of lever presses and infusions were recorded.

Verification of cannula placement. On conclusion of behavioral experiments, rats (except those designated for epigenetic analysis) were anesthetized and transcardially perfused with PBS followed by $4 \%$ PFA. Brains were removed and immersed in $4 \%$ PFA for $24 \mathrm{~h}$, then in phosphate buffer with $30 \%$ sucrose for $48 \mathrm{~h}$. Brains were then frozen on dry ice and sliced (40 $\mu \mathrm{m}$ sections) with a cryostat. Sections were mounted on glass slides coated with $2 \%$ gelatin, and cannula placement (see Fig. $1 D$ ) was verified under a microscope. Average hit rate was $85 \%$. Data were analyzed only in rats in which the guide cannula was accurately implanted ( 8 rats were excluded because of misplacement or general weakness).

Preparation of tissue punches for NAc isolation. On day 1 or 30 of withdrawal, or immediately after the extinction tests on day 1 or day 30 , serial $1 \mathrm{~mm}$ brain sections were cut and placed on chilled microscope slides. Tissue punches of the NAc were procured rapidly, using a stainless steel cannula with an inner diameter of $1.1 \mathrm{~mm}$. Tissue samples were immediately frozen on dry ice and stored at $-80^{\circ} \mathrm{C}$ for further epigenetic or protein analysis.

Methylated DNA immunoprecipitation (MeDIP) and labeling. Briefly, for the first series of experiments (assessment of DNA methylation after 1 or $30 \mathrm{~d}$ of cocaine withdrawal and after extinction tests), 3 pools of NAc DNA, each including the DNA of 2 or 3 rats, were used per condition (total 8 rats per condition). Each pool was made up of $2 \mu \mathrm{g}$ DNA $(2 \times 1$ $\mu \mathrm{g}$ for pools of 2 rats, $3 \times 700 \mathrm{ng}$ for pools of 3 rats) that were sonicated. For the second series of experiments (RG108, SAM, and aCSF treatments), no pools were used; thus, each array corresponded to 1 single rat. In total, we used 3 RG108-treated, 4 SAM-treated, and 3 aCSF-treated rats; $2 \mu \mathrm{g}$ DNA from the NAc of each single rat was sonicated. After the sonication step, methylated DNA was immunoprecipitated with $10 \mu \mathrm{g}$ of anti-5-methylcytosine antibody (Calbiochem) that is specific to DNA methylation, does not recognize hydroxymethylated DNA, and reveals changes in 5-methylcytosine exclusively. Before sonication, two control plasmids were added to the DNA (6 pg each): an unmethylated GFP plasmid and an in vitro methylated Luciferase plasmid. The DNAantibody complex was immunoprecipitated with $5 \mathrm{mg}$ protein $\mathrm{A}$, and the methylated DNA was eluted with $150 \mu \mathrm{l}$ of TE at $1.5 \%$ SDS. The input and bound fractions were then purified, and specificity for methylated DNA and the absence of nonspecific binding were validated by PCR analysis for two control genes, H19 (methylated control) and GAPDH (unmethylated control), and the two added plasmids, GFP (unmethylated control) and Luciferase (in vitro methylated control), using the following primers: H19: forward (5'-TTGGTGGAACACGCTGTGATCA-3'), reverse (5'-GAGCCGCACCAGGTCTTCAG-3'); GAPDH: forward (5'-TTTCTTTCCTTTCGCGCTCTG-3'), reverse (5'-CCATTCATT TCCTTCCCGGTT-3'); GFP: forward ( $5^{\prime}$-CAAGGGCGAGGAGCTGTT$\left.3^{\prime}\right)$, reverse (5'-CGGCCATGATATAGACGTTG-3'); MeLuciferase: forward (5'-AGAGATACGCCCTGGTTCC-3'), reverse (5'-CCAACACCGGCATAAAGAA- $\left.3^{\prime}\right)$. The input and bound fractions were then amplified using the Whole Genome Amplification kit (Sigma). The amplified input and bound fractions were labeled for microarray hybridization with either Cy3-dUTP or Cy5-dUTP (PerkinElmer), respectively, using the CGH labeling kit (Invitrogen) following the manufacturer's instructions.

MeDIP microarray design, hybridization, scanning, and analysis. For MeDIP enrichment, custom 400K promoter tiling array designs were used (Agilent Technologies). Microarray probe sequences were selected to tile at $100 \mathrm{bp}$, spacing all gene promoter regions defined as the genomic interval from $-1000 \mathrm{bp}$ upstream to $250 \mathrm{bp}$ downstream of each transcription start site as defined for the rat genome by the Ensembl database (version 60.34b) (http://www.ensembl.org).

In addition, we selected 47 candidate genes to analyze in this study. These genes, previously associated with drug addiction, included the following: Arc, Cdk5, Creb1, Crebbp, Ddr1, Dlg4, Dnmt1, Dnmt3a, Drd1a, Drd2, Ehmt2, Fos, Fosb, Gabrd, Gdnf, Gpr156, Gria2, Grin1, Grin2a, Grin2b, Grm2, Grm3, Grm5, Hdac1, Hdac5, Homer1, Homer2, Igf2, LOC367858, LOC691178, Mapk1, Mapk3/4/6/9/10/11/12/13/14/ 15, Nfkb1, Ntrk2, Q1LZ51, Rac1, Sirt1, and Sirt2. The candidate genes were tiled from $-50 \mathrm{~kb}$ of the transcription start site to $50 \mathrm{~kb}$ after the transcription end site.

All the steps of hybridization, washing, scanning, and feature extraction were performed following the Agilent Technologies protocols for chip-on-chip analysis (MeDIP). After microarray scanning, probe intensities were extracted from scan images using Agilent's Feature Extraction 10.5 Image Analysis Software (Agilent Technologies). The extracted intensities were then analyzed using the $\mathrm{R}$ software environment for statistical computing. Log ratios of the bound (Cy5) and input (Cy3) microarray channel intensities were computed for each microarray, and then microarrays were normalized to one another using quantile normalization under the assumption that all samples have identical overall methylation levels.

The lists of differentially methylated regions between groups of samples were determined in stages to ensure both statistical significance and biological relevance. In the first stage, linear models implemented in the "limma" package of Bioconductor were used to compute a modified $t$-statistic from the normalized intensities of the probes across all samples between the two groups. An individual probe was considered differentially methylated if the significance of its $t$-statistic was at most 0.01 (uncorrected for multiple testing) and the associated difference of means between the groups was at least 0.5 . We calculated the significance of enrichment for high- or low-probe $t$-statistics of all probes within each gene promoter $(-1000 \mathrm{bp}$ to $250 \mathrm{bp}$ of the transcription start site). Significance was determined using the Wilcoxon rank-sum test compar- 

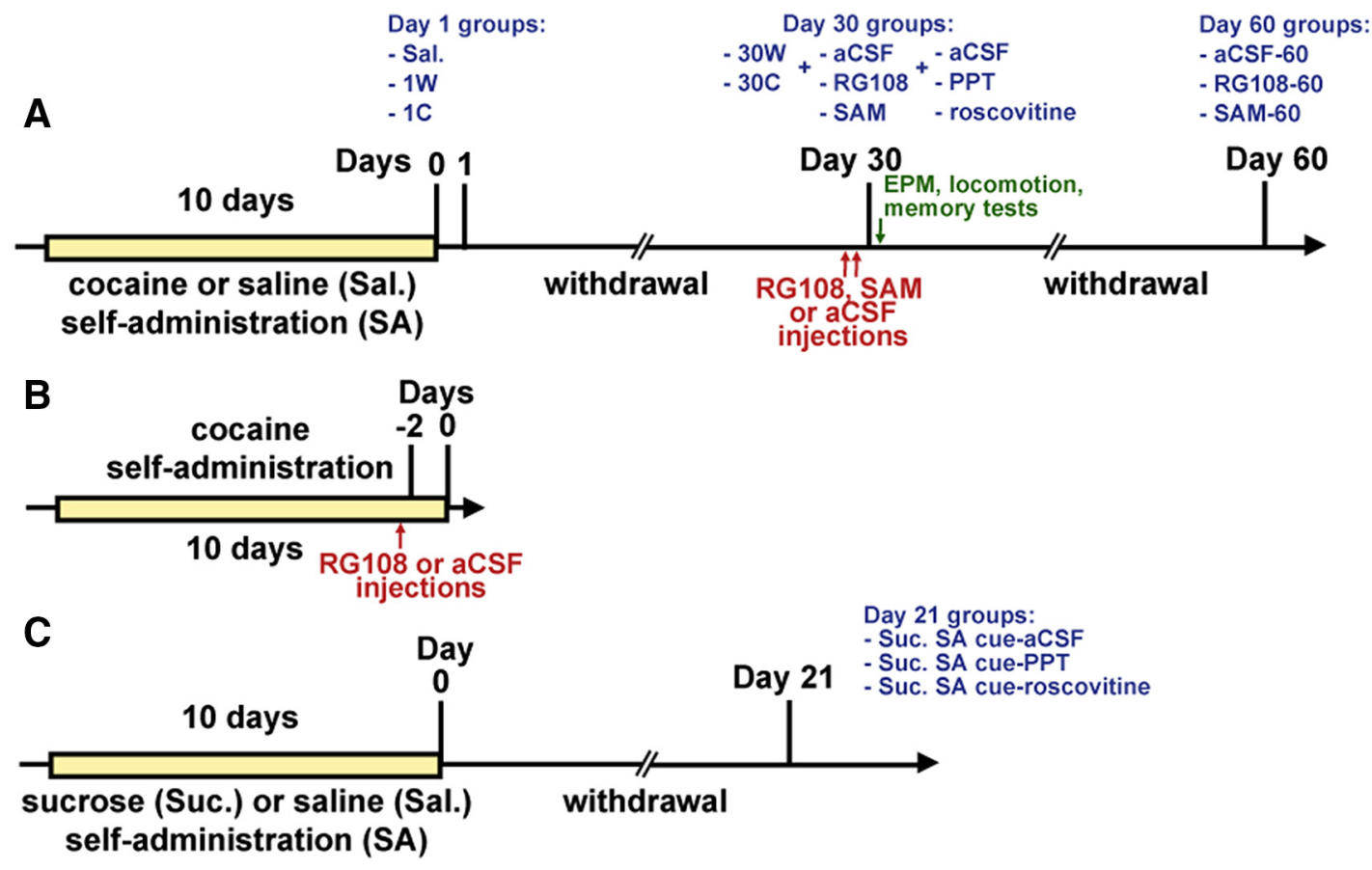

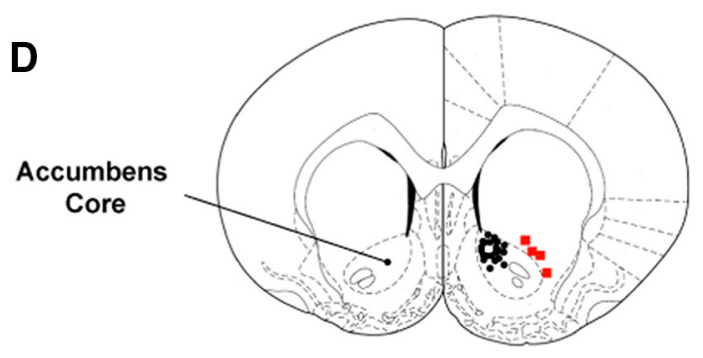

Bregma $+1.2 \mathrm{~mm}$

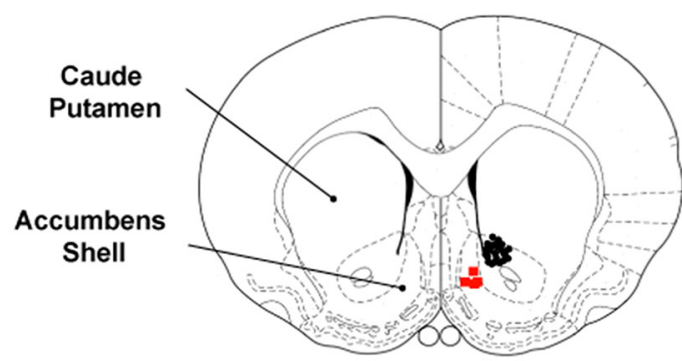

Bregma $+1.6 \mathrm{~mm}$

Figure 1. Experimental design. $A$, In the first experiment, rats trained for cocaine self-administration (SA) were subjected to withdrawal (W) periods of 1 or $30 \mathrm{~d}$ (1W/30W). Some rats were subjected to an extinction test and assessed for cue-induced cocaine seeking on day 1 or 30 of withdrawal (1C or 30C). Controls self-administered saline. Rats were analyzed for DNA methylation and mRNA expression differences at these four time points. In the second experiment, rats trained for cocaine $S A$ were subjected to $30 \mathrm{~d}$ of withdrawal, then treated with intra-NAc injections of RG108, SAM, or aCSF (as control), and tested for cue-induced cocaine seeking on day 30 and on day 60. DNA methylation, mRNA expression, and protein levels, in addition to anxiety-related behavior, locomotion, and memory, were analyzed in these groups on day 30 after cue testing. In a third experiment, rats trained to self-administer cocaine were withdrawn for $30 \mathrm{~d}$, then treated with an intra-NAc injection of the estrogen receptor agonist PPT or the CDK5 inhibitor roscovitine (or aCSF as control), and subjected to an extinction test. $\boldsymbol{B}$, A group of control rats were given intra-NAc RG108 or aCSF injections on day 8 of SA training. C, Rats trained for sucrose SA were subjected to a W period of $21 \mathrm{~d}$, then treated with an intra-NAc injection of PPT or roscovitine (or aCSF as control), and subjected to an extinction test. $\boldsymbol{D}$, Representative image for cannula placement in the NAc. Circles represent cannulas in place. Squares represent misplacements.

ing $t$-statistics of these probes against those of all the probes on the microarray. The resulting $p$ values for each gene were then corrected for multiple testing by calculating their false discovery rate (FDR). A gene promoter was then considered differentially methylated if its FDR was at most 0.2 and if one of its probes was considered differentially methylated.

For biological function analyses, selected genes were overlaid on the global molecular network developed from information contained in the Ingenuity Pathway Knowledge Base (www.ingenuity.com). This network is composed of $>3.5$ million literature-based biological links between genes and bioactive molecules. Subnetworks are built on genes of interest based on their connectivity within this global network, taking into account the relative numbers of network eligible molecules, molecules analyzed, and total number of molecules in Ingenuity's knowledge base. The top biological functions associated with each network are determined by querying the Ingenuity Pathways Knowledge Base for relationships between the genes in the network and the cellular and organismal functions they impact. The significance of the association between the network and those biological functions is scored using a $p$ value calculation (right-tailed Fisher's exact test).
cDNA microarray hybridization and analysis. Briefly, double-stranded cDNA was synthesized from total RNA from the NAc of all rats used for the first series of MeDIP enrichments (withdrawal and cue). In vitro transcription was performed to produce biotin-labeled cDNA using Affymetrix Gene Chip 3' IVT Express reagent kit according to the manufacturer's instructions (Affymetrix). After fragmentation, $12.5 \mu \mathrm{g}$ of cDNA was hybridized to Affymetrix Rat Gene 1.0 ST microarrays interrogating 27,342 genes. GeneChips were then scanned with the GeneChip scanner 3000 (Affymetrix). Microarray probe intensities were normalized to each other using Robust Multiarray Average. Expression differences between groups were then obtained by applying linear models implemented in the "limma" package of Bioconductor to obtain modified $t$-statistics and corresponding $p$ values. $p$ values were not adjusted for multiple testing because the main purpose of the gene expression profiles was not to identify transcriptional associations in isolation, but to integrate these associations with DNA methylation associations with incubation of cocaine craving.

Data files for expression and DNA methylation analysis: All microarray data files will be deposited in Gene Expression Omnibus (GEO) at NCBI (http://www.ncbi.nlm.nih.gov/geo/query/acc.cgi?acc=GSE66350). 
A

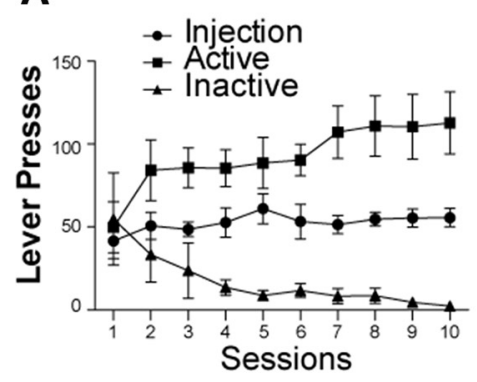

D

\section{Heatmap of the genome-wide promoter analysis}

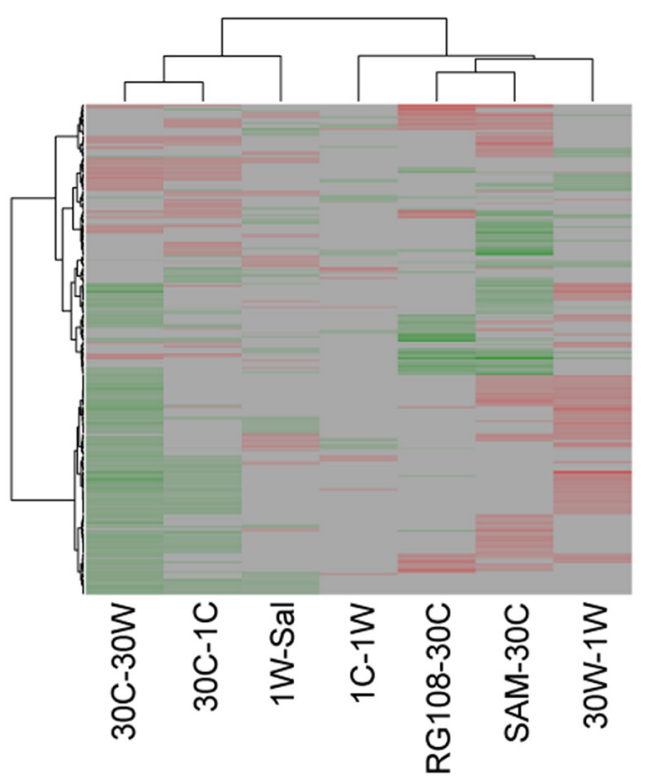

B

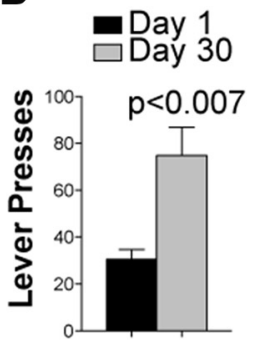

C

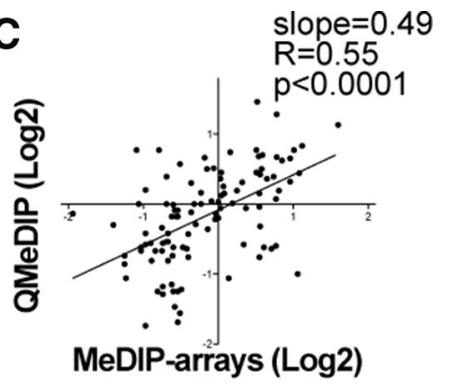

E
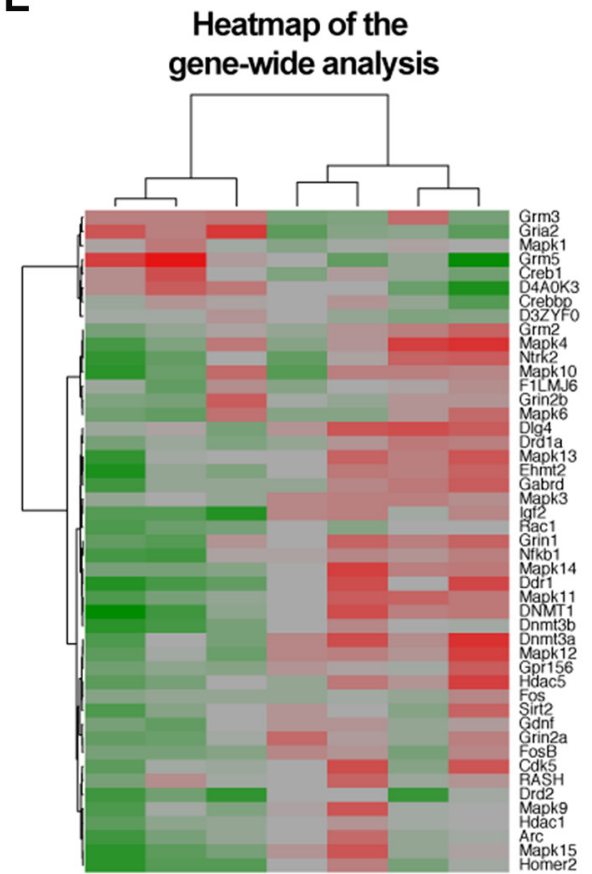

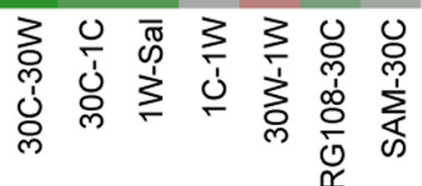

Figure 2. DNA methylation dynamics during incubation of cocaine craving. $A$, During cocaine self-administration training sessions $(0.75 \mathrm{mg} / \mathrm{kg}$ cocaine, $6 \mathrm{~h}$ per day for $10 \mathrm{~d}$, FR-1 pairing active lever presses with light cue), rats demonstrated a significantly higher amount of active lever pressing compared with the inactive lever (one-way ANOVA with repeated measures, $p<0.01$ ). Shown are average numbers of active and inactive lever presses, and intravenous cocaine injections \pm SEM. $\boldsymbol{B}$, Extinction test after $1 \mathrm{~d}$ versus $30 \mathrm{~d}$ of withdrawal. "Incubated" (high) cue-induced cocaine seeking is seen after prolonged withdrawal compared with early withdrawal ( $p<0.0032$, Welch's $t$ test; $n=9$ per group). Results show mean number of active lever presses \pm SEM. C, Correlation between $\mathrm{PPCR}-\mathrm{MeDIP}$ measurements of methylation and MeDIP array values for the same regions. $\boldsymbol{D}$, Hierarchical clustering of promoter methylation differences derived from the whole-genome analysis. Promoters are included if they contain a significantly differentially methylated region in at least one group comparison. Coloring represents the mean differences of the normalized probe intensities between the treatment groups. Red represents that the region has significantly higher methylation in the first compared with the second group. Green represents the second group has significantly higher methylation than the first group. Gray represents no significant difference between the groups. Sal, Saline control; $1 \mathrm{~W}$, day 1 withdrawal; $30 \mathrm{~W}$, day 30 withdrawal; $1 \mathrm{C}$, day 1 cue responding; $30 C$, day 30 cue responding. For example, $1 C-1 W$ compares the state of methylation after day 1 extinction test versus the state of methylation after day 1 withdrawal. $\boldsymbol{E}$, Hierarchical clustering of methylation differences derived from analysis of the 47 candidate genes. Green represents hypomethylation. Red represents hypermethylation.

Heatmaps. Figure 2 shows heatmaps composed for promoters (2D) or gene bodies (2E) (rows) and treatment group comparisons (columns). Promoters or genes are included if they contain a significantly differentially methylated region in at least one group comparison. Coloring corresponds to the mean differences of the normalized probe intensities between the groups, where red represents that the region has significantly higher methylation in the first compared with the second group, green represents the second group has significantly higher methylation than the first group, and gray represents no significant difference between the groups. For example, for the column labeled $1 \mathrm{C}-1 \mathrm{~W}$, red represents that the day 1 cue (1C) group is more methylated than the day 1 withdrawal (1W) group.

Validation. Gene-specific real-time PCR validations of MeDIP microarrays were performed on the amplified and input bound frac- tions. Relative enrichment was determined after normalizing from the input fraction in each sample. For qPCR validations of expression arrays, cDNA synthesis was performed using random hexamer primers (Invitrogen) according to the manufacturer's instructions. GAPDH was used as the reference gene. SYBR Green qRT-PCR was performed using the LightCycler 480 system (Software 3.5, Roche Molecular Biochemicals). To determine the relative concentration of mRNA expression, the $2^{-\Delta \Delta \mathrm{Ct}}$ method was used. The Student's unpaired one-tailed $t$ test or one-way ANOVA was used, and the $\alpha$ level was set at 0.05 . GraphPad 5 software was used to perform statistical analysis.

Western blotting. For protein analysis, NAc of rats treated with RG108, SAM, or aCSF ( $n=6,5$, and 4 , respectively) on day 30 were analyzed. 
Table 1. Genes selected for gene-wide DNA methylation analysis ${ }^{a}$

\begin{tabular}{|c|c|c|c|}
\hline Genes & Promoters & Gene-wide & Region-specifi \\
\hline Arc & + & & + \\
\hline Cdk5 & & & + \\
\hline Creb1 & & + & \\
\hline Crebbp & & + & \\
\hline Ddr1 & & + & \\
\hline Dlg4 & & + & \\
\hline DNMT1 & & + & \\
\hline Dnmt3a & & + & \\
\hline \multicolumn{4}{|l|}{ Drd1a } \\
\hline \multicolumn{4}{|l|}{ Drd2 } \\
\hline Ehmt2 & & + & \\
\hline Fos & - & & - \\
\hline FosB & & & + \\
\hline Gabrd & & + & \\
\hline \multicolumn{4}{|l|}{ Gdnf } \\
\hline Gpr156 & & & Mix \\
\hline \multicolumn{4}{|l|}{ Gria1 } \\
\hline Gria2 & - & - & \\
\hline Grin1 & & + & \\
\hline Grin2a & & Mix & \\
\hline Grin2b & & Mix & \\
\hline Grm2 & Mix & & + \\
\hline Grm3 & - & & - \\
\hline Grm5 & & - & \\
\hline Hdac1 & & & + \\
\hline Hdac5 & & & + \\
\hline Homer1 & & & - \\
\hline Homer2 & & Mix & \\
\hline $\operatorname{lgf} 2$ & & + & \\
\hline \multicolumn{4}{|l|}{ LOC367858 } \\
\hline \multicolumn{4}{|l|}{ LOC691178 } \\
\hline Mapk1 & & & - \\
\hline Mapk10 & Mix & + & \\
\hline Mapk11 & & & Mix \\
\hline Mapk12 & & & + \\
\hline Mapk13 & + & & + \\
\hline Mapk14 & & + & \\
\hline Mapk15 & & & + \\
\hline Mapk3 & & & Mix \\
\hline Mapk4 & & Mix & \\
\hline Mapk6 & & & - \\
\hline Mapk9 & & & + \\
\hline Nfkb1 & & Mix & \\
\hline Ntrk2 & & Mix & \\
\hline \multicolumn{4}{|l|}{ Rac1 } \\
\hline Sirt1 & & & - \\
\hline Sirt2 & & & \\
\hline
\end{tabular}

${ }^{a}$ Genes were affected during the withdrawal period ( $30 \mathrm{~W}$ vs $1 \mathrm{~W}$ ) gene widely, in specific gene regions, or only in promoters. Indicated are genes that were only hypermethylated $(+)$, only hypomethylated $(-)$, or both hypermethylated and hypomethylated ("mix") compared with $1 \mathrm{~d}$ of withdrawal.

NAc were rapidly sampled $1 \mathrm{~h}$ after the extinction test and frozen in liquid nitrogen. For protein extractions, NAc were washed with cold PBS and homogenized in lysis buffer (10 mM HEPES, pH 7.4, 1 mM EDTA, 2 mM EGTA, $0.5 \mathrm{~mm}$ DTT, phosphatase, and protease inhibitors mixture, Complete, Roche) using a rotor stator homogenizer. NAc were then briefly sonicated and centrifuged for $10 \mathrm{~min}$ at 13,000 rpm, and the supernatant was used for Western blot analysis. Protein concentration was determined using the Bradford method (Bio-Rad assay). A total of 40 $\mu \mathrm{g}$ of proteins was loaded on $10 \%$ SDS-PAGE gels and transferred onto nitrocellulose membranes (Bio-Rad). Blots were blocked for $60 \mathrm{~min}$ in PBS with Tween 20 containing 5\% (w/v) nonfat dry milk. Antibodies used were anti-H2B (1:1000; Abcam; Ab1790), anti-NMDAR2A (1:1000; Millipore; AB1555P), anti-ESR1 (1:1000; Millipore; 04820), anti-GluR1 (GluA1) (1:500; Millipore; ABN241), and HRP-conjugated anti-rabbit (1:80,000; Sigma-Aldrich; A0545). Membranes were revealed using
Western Lightning Plus ECL (PerkinElmer), signal quantification was done using ImageJ, and protein level was normalized relative to H2B.

Statistical analysis. One-way ANOVA with or without repeated measures followed by Student-Newman-Keuls' was used to determine differences within or between multiple groups. Two-way ANOVA with repeated measures followed by Student-Newman-Keuls' was used to examine the effect of treatment in the object recognition test. For MeDIP microarrays, a probe was considered differentially methylated if the significance of its moderated $t$-statistic was at most 0.01 and the associated difference of means between the groups was at least 0.5 . Significance was then determined using the Wilcoxon rank-sum test comparing $t$-statistics of these probes against those of all the probes on the microarray. The resulting $p$ values for each gene were then corrected for multiple testing by calculating their FDR. For cDNA microarrays, $p$ values were calculated from moderated $t$-statistics. For qPCR experiments, Student's $t$ test or Welch's $t$ test were used to determine differences between two groups. $p<0.05$ was considered significant. Results are presented as mean \pm SEM.

\section{Results}

\section{Effect of short and prolonged withdrawal periods on NAc DNA methylation}

Rats were trained to self-administer cocaine for $10 \mathrm{~d}$ during which they demonstrated reliable cocaine self-administration behavior determined by the number of active lever presses, which were significantly higher than inactive lever presses (one-way ANOVA with repeated measures: $F_{(2,32)}=28, p<0.01$; Figs. $1 A$ and $2 A$ ). Control rats that underwent saline self-administration showed no change in active lever pressing compared with inactive lever pressing. After a period of forced withdrawal (W) for either 1 or $30 \mathrm{~d}(1 \mathrm{~W}, 30 \mathrm{~W})$, cue-induced cocaine seeking (C) was assessed in an extinction test at 1 or $30 \mathrm{~d}(1 \mathrm{C}, 30 \mathrm{C})$ (Figs. $1 \mathrm{~A}$ and $2 B)$. We found a significantly higher number of active lever presses during the extinction test on day 30 compared with day 1 (Welch's $t$ test, $t_{(16)}=3.471 ; p<0.0032$ ) (Fig. $2 B$ ), demonstrating a process of incubation of cocaine craving.

Brains were extracted and the NAc isolated from cocainetrained rats after withdrawal or extinction testing on day 1 and 30 (1W, 30W, $1 \mathrm{C}$, or 30C, respectively), or from saline-trained rats after saline "withdrawal" on day 1 (Sal) (Fig. 1A). To analyze DNA methylation profiles in the NAc, we combined unbiased whole-genome and candidate gene approaches. We created custom high-density oligonucleotide arrays for genome-wide promoter methylation analysis and gene-wide methylation analysis (Table 1), then confirmed differential methylation for several significant probes (23 genes for a total of 107 comparisons) by qPCR after methylation enrichment. We found a significant positive correlation between results obtained by array and quantitative PCR analysis $(r=0.55, p<0.0001$; Fig. $2 C)$. We then clustered comparisons between the experimental conditions, by overlapping differentially methylated regions and analyzing their dynamics (Fig. 2D,E). Our analysis revealed several findings on DNA methylation changes in the process of incubation of cocaine craving.

First, we found that all 47 candidate genes that were selected for this study, and that were previously suggested to have a role in drug addiction, showed alterations in DNA methylation states (hypermethylation or hypomethylation) during short or prolonged withdrawal (Fig. 2E). We tiled the entire loci of these candidate genes to determine whether specific regions outside the promoter area (which might be missed by promoter arrays) may be particularly involved in regulation of these genes by DNA methylation. We found that DNA methylation changes occurred during short or prolonged withdrawal throughout the span of 40 of these 
Table 2. Number of genes and probes differentially methylated under the various experimental conditions ${ }^{a}$

\begin{tabular}{|c|c|c|c|c|}
\hline & \multicolumn{2}{|c|}{ Genome-wide promoter analysis (no. of genes) } & \multicolumn{2}{|c|}{ Gene-wide analysis (no. of probes) } \\
\hline & Hypermethylated & Hypomethylated & Hypermethylated & Hypomethylated \\
\hline Early changes $(1 \mathrm{~W}-\mathrm{Sal})^{b}$ & 423 & 385 & 610 & 548 \\
\hline Effect of cue compared with early changes $(1 C-1 W)^{c}$ & 63 & 146 & 94 & 195 \\
\hline Withdrawal changes $(30 \mathrm{~W}-1 \mathrm{~W})^{d}$ & 871 & 488 & 1180 & 664 \\
\hline $\begin{array}{l}\text { Effect of cue compared with late changes } \\
(30 \mathrm{C}-30 \mathrm{~W})^{e}\end{array}$ & 1706 & 2456 & 2439 & 3730 \\
\hline $\begin{array}{l}\text { Effect of SAM treatment in response to cocaine- } \\
\text { associated cue on day } 30(30 C ; \text { SAM-aCSF })^{f}\end{array}$ & 1666 & 1452 & 1068 & 633 \\
\hline $\begin{array}{l}\text { Effect of RG108 treatment in response to cocaine- } \\
\text { associated cue on day } 30(30 C ; \text { RG108-aCSF) }\end{array}$ & 583 & 488 & 222 & 230 \\
\hline \multicolumn{5}{|l|}{${ }^{a} p<0.01(F D R<0.2)$} \\
\hline \multicolumn{5}{|c|}{${ }^{b}$ Rats after $1 \mathrm{~d}$ of cocaine withdrawal (W) compared with rats after $1 \mathrm{~d}$ of saline "withdrawal." } \\
\hline \multicolumn{5}{|c|}{ 'Rats tested for extinction responding (cue-induced cocaine seeking [C] at day 1 compared with day 1 withdrawal. } \\
\hline \multicolumn{5}{|l|}{ ¿ ${ }^{\text {Rats after } 30 \mathrm{~d} \text { withdrawal compared with } 1 \mathrm{~d} \text { withdrawal. }}$} \\
\hline \multicolumn{5}{|c|}{ ${ }^{2}$ Rats tested for extinction responding on day 30 compared with day 30 withdrawal. } \\
\hline
\end{tabular}

genes at exons, introns, promoters, intergenic regions, and at the $3^{\prime}$. No specific enrichment of methylation changes was observed in any of these particular genomic regions given their relative sizes. We observed significant correlation between all anatomical regions of these genes. The breadth of changes in DNA methylation across a gene, however, was different for different gene loci (Table 1).

Next, we found that many other promoters in the genomewide screen showed a changed state of DNA methylation after both short and prolonged withdrawal. Interestingly, the number of differentially methylated promoters after prolonged cocaine withdrawal (day 30 compared with day $1[30 \mathrm{~W}-1 \mathrm{~W}]=$ 1359 genes, $p<0.01$, FDR $<0.2$ ) was double the number of differentially methylated promoters after early cocaine withdrawal (day 1 compared with saline controls [1W-Sal] $=809$ genes, $p<0.01$, FDR $<0.2$ ) (Fig. $2 D$; Table 2). Using Ingenuity Pathway Analysis, we found that promoters whose state of methylation changed during the prolonged withdrawal period are functionally related to the following functional pathways: "Cancer" $\left(p=1.34 \mathrm{E}^{-13}\right)$, "Morphology of cells" $(p=$ $6.96 \mathrm{E}^{-7}$ ) (see Table 3), and canonical pathways, such as "Ephrin Receptor Signaling" ( $\left.p=2.97 \mathrm{E}^{-3}\right)$, "Neurotrophin Signaling" $\left(p=5.19 \mathrm{E}^{-3}\right)$, "Glucocorticoid Receptor Signaling" ( $p=$ $\left.2.01 \mathrm{E}^{-2}\right)$, or "Synaptic Long-term Depression" $\left(p=2.03 \mathrm{E}^{-2}\right)$, the members of which (e.g., Grm3, Gria2, Nr3C1) have been associated with self-administration motivation, incubation of craving, and reinstatement of drug seeking (Deroche-Gamonet et al., 2003; Conrad et al., 2008; Moussawi and Kalivas, 2010).

We next examined the different directions of DNA methylation changes. After early withdrawal (1W-Sal), these changes occurred in both directions; some genes became more methylated and others became demethylated. Over prolonged withdrawal, we found that some of these changes remained stable (30W-1W; total of 175 genes), as is anticipated from a stable epigenetic mark of cocaine exposure. Examples include Creb1 and corticotropin-releasing hormone (Crhr1), which were both previously associated with addiction to drugs of abuse, and with the effects of cocaine in particular (Basso et al., 1999; Koob, 1999; Lê et al., 2000; Feng et al., 2006; Huang et al., 2008; Tropea et al., 2008; Robison and Nestler, 2011; Madsen et al., 2012; Contoreggi et al., 2013). However, other DNA methylation alterations that were observed during early withdrawal showed time-dependent changes, in different routes. Some genes (including 33 promoters) showed a time-dependent enhancement in their methylation state, in the same trend as during early withdrawal: that is, these genes were even more methylated or more demethylated after prolonged withdrawal (e.g., Grin $2 a$; 3Fig. 3; another example is $N r 3 c 1$, which is involved in modulation of cocaine self-administration in rats vulnerable to develop addiction) (Deroche-Gamonet et al., 2003). Conversely, other genes (including 80 promoters) showed a time-dependent reversal of the methylation changes observed during early withdrawal (Fig. 3; e.g., Grm3; also see heatmaps in Fig. 2D). An additional route that was observed included a large number of newly differentially methylated regions that appeared only after the prolonged withdrawal period (1246 genes; 30W-1W; e.g., Gad1; Fig. 3).

\section{Effect of cue-induced cocaine seeking after withdrawal on NAc DNA methylation}

Surprisingly, given the perceived stability of DNA methylation, cue-induced cocaine seeking on day 1 or day 30 induced hundreds of methylation changes within $1 \mathrm{~h}$. Moreover, cue-induced cocaine seeking at day 30 had a much more profound impact on the NAc DNA methylation profile than at day $1(1 \mathrm{C}-1 \mathrm{~W}=209$ genes; $30 \mathrm{C}-30 \mathrm{~W}=4162$ genes, $p<0.01$, FDR $<0.2$ ), with only a small set of genes showing a significant overlap ( 54 genes showing common differential methylation between day $1 \mathrm{C}$ and 30C; $p=$ 0.032, hypergeometric test). The extent of DNA methylation changes (see heatmaps) mirrors the time-dependent increase in cue-induced cocaine seeking (Fig. 2B).

Interestingly, cue-induced cocaine seeking generally reversed methylation changes triggered by withdrawal (1C-1W vs $1 \mathrm{~W}-\mathrm{Sal}$, 51 genes; $30 \mathrm{C}-30 \mathrm{~W}$ vs $30 \mathrm{~W}-1 \mathrm{~W}, 746$ genes; Figs. $2 \mathrm{D}, \mathrm{E}$ and 3, Gad1, slc43a3, Grm3 as examples; Table 3). This is shown by the inverse correlations between methylation levels of gene promoters or gene bodies affected by the withdrawal and the cue at day 1 (1C-1W vs $1 \mathrm{~W}$-Sal; genome-wide promoter analysis: $r=-0.21$, $p=6 \mathrm{E}^{-4}$; Fig. $2 D$; gene-wide analysis: $r=-0.57, p=2 \mathrm{E} 10^{-5}$; Figure $2 E$ ), or those at day 30 (30C-30W vs $30 \mathrm{~W}-1 \mathrm{~W}$; genomewide promoter analysis: $r=-0.61, p=2 \mathrm{E}^{-27}$; Fig. $2 D$; genewide analysis: $r=-0.6, p=9 \mathrm{E}^{-6}$; Fig. $2 E$ ).

\section{Transcriptional response to withdrawal and cue-induced cocaine seeking}

We used Affymetrix microarrays to analyze the transcriptional response during the withdrawal periods and subsequent extinction tests. 
Table 3. Examples of genes enriched in specific biological functions

\begin{tabular}{|c|c|c|c|c|c|}
\hline \multirow[b]{2}{*}{ Biological functions } & \multirow[b]{2}{*}{$p$ values } & \multicolumn{4}{|l|}{ Genes } \\
\hline & & $\begin{array}{l}\text { Methylation status at } \\
\text { day } 30 \text { compared } \\
\text { with day } 1 \text { ( } 30 \mathrm{~W}-1 \mathrm{~W})\end{array}$ & $\begin{array}{l}\text { Nondifferentially methylated at day } \\
30 \text { after the cue compared with } \\
30 \mathrm{~W}(30 \mathrm{C}-30 \mathrm{~W})\end{array}$ & $\begin{array}{l}\text { Hypomethylated at day } 30 \text { after the cue compared with } \\
30 \mathrm{~W}(30 \mathrm{C}-30 \mathrm{~W})\end{array}$ & $\begin{array}{l}\text { Hypermethylated at day } 30 \text { after the } \\
\text { cue compared with } 30 \mathrm{~W}(30 \mathrm{C}-30 \mathrm{~W})\end{array}$ \\
\hline
\end{tabular}


Table 3. Continued

\begin{tabular}{|c|c|c|c|c|c|}
\hline \multirow[b]{2}{*}{ Biological functions } & \multirow[b]{2}{*}{$p$ values } & \multicolumn{4}{|l|}{ Genes } \\
\hline & & $\begin{array}{l}\text { Methylation status at } \\
\text { day } 30 \text { compared } \\
\text { with day } 1 \text { (30W-1W) }\end{array}$ & $\begin{array}{l}\text { Nondifferentially methylated at day } \\
30 \text { after the cue compared with } \\
30 \mathrm{~W}(30 \mathrm{C}-30 \mathrm{~W})\end{array}$ & $\begin{array}{l}\text { Hypomethylated at day } 30 \text { after the cue } \\
\text { compared with } 30 \mathrm{~W}(30 \mathrm{C}-30 \mathrm{~W})\end{array}$ & $\begin{array}{l}\text { Hypermethylated at day } 30 \text { after the } \\
\text { cue compared with } 30 \mathrm{~W}(30 \mathrm{C}-30 \mathrm{~W})\end{array}$ \\
\hline \multirow[t]{2}{*}{ Morphology of the cells } & $6.96 \mathrm{E}-07$ & Hypermethylated & $\begin{array}{l}\text { ABCG1, ACVRL1, AGR2, ASZ1, ATG7, } \\
\text { CEBPB, CREB3L4, DNA2, FST, } \\
\text { GNA11, HADHA, HES5, IL10, } \\
\text { ITGB8, LMNA, MAPK8IP2, MPRIP, } \\
\text { MYH6, OSM, PICK1, PLA2G4A, } \\
\text { POMC, POMGNT1 }\end{array}$ & $\begin{array}{l}\text { AGER, AIRE, ARID3A, ATP4B, BBS2, BCAR1, } \\
\text { CACNA1A, CADPS, CCKBR, CD5, CDKN2C, } \\
\text { CHMP2A, CTSD, DES, DFNB31, DKK3, DLK1, } \\
\text { ECEL1, ELF4, ERC2, F7, FAIM2, FAT1, FBLIM1, } \\
\text { FSCN2, GAD1, GDF15, GPR37L1, GRK1, H0R- } \\
\text { MAD1, KIF26A, KLF1, LAT2, LGMN, LHB, LIF, } \\
\text { LIMK1, LTB, MAB21L2, MST1R, MYH2, NEK6, } \\
\text { NOS1, PAK4, PBX1, PGR, PLEC, }\end{array}$ & AP2M1, PLA2G15 \\
\hline & & Hypomethylated & $\begin{array}{l}\text { ACTR2, CHFR, CTSB, DGAT2, FABP9, } \\
\text { GAP43, IL5RA, NET1, PDPK1, } \\
\text { PEBP1, RAP1A, SPINK5, SPRY2, } \\
\text { TAC1, USP1 }\end{array}$ & CAPZB, KIF3B & $\begin{array}{l}\text { ABL1, ATE1, EBF1, F0S, GCLM, } \\
\text { GSK3A, ID01, IGF1, IL1B, LIG4, } \\
\text { MAP2K6, MARCKSL1, NPEPPS, } \\
\text { NR3C1, 0AT, PHLDA1, PIP5K1A, } \\
\text { PPARGC1A, RRAS2, SLC11A2, } \\
\text { SMC2 }\end{array}$ \\
\hline \multirow[t]{2}{*}{$\begin{array}{l}\text { Morphology of nervous } \\
\text { tissue }\end{array}$} & $3.27 \mathrm{E}-05$ & Hypermethylated & $\begin{array}{l}\text { DUOXA1, FST, GMFB, HES5, HOXB1, } \\
\text { HOXB6, ITGB8, LMNA, } \\
\text { MAPK8IP2, OSM }\end{array}$ & $\begin{array}{l}\text { BBS2, CACNA1A, CADPS, CBLN3, CDKN2C, } \\
\text { CELSR2, CTSD, CYP26C1, ECEL1, EFHC1, ERC2, } \\
\text { FAIM2, GAD1, GPR37L1, KIF226A, LIF, LIMK1, } \\
\text { MAB21L2, MAGED1, N0S1, PAK4, PLEC }\end{array}$ & \\
\hline & & Hypomethylated & $\begin{array}{l}\text { B4GALT2, CNTN4, CTSB, GAP43, } \\
\text { HESX1, NCAM2, PDPK1, PRNP, } \\
\text { SPRY2, TAC1 }\end{array}$ & CAPZB, KIF3B & $\begin{array}{l}\text { ABL1, CEP290, EBF1, ETV1, GCLM, } \\
\text { GRIA2, IGF1, IL1B, LIG4, } \\
\text { MARCKSL1, 0AT, PPARGC1A }\end{array}$ \\
\hline \multirow[t]{2}{*}{ Cell death } & 4.10E-05 & Hypermethylated & $\begin{array}{l}\text { ABCG1, ACVRL1, AGAP3, AGR2, } \\
\text { ALD0A, ALX3, ARC, ASS1, ATF6, } \\
\text { ATG3, ATG7, C10TNF4, CCNE1, } \\
\text { CEBPB, COPS5, CUL5, EIF2AK4, } \\
\text { FST, GCGR, GMFB, GNA11, } \\
\text { GUCA2B, HADHA, H0XA13, } \\
\text { H0XB1, IL10, IL12A, KRT19, } \\
\text { LMNA, MEF2A, MELK, MPRIP, } \\
\text { MRPL41, MSH3, MYH6, NFE2L1, } \\
\text { OSM, PCBP4, PICK1, PLA2G10, } \\
\text { PLA2G4A, PLD2, P0MC }\end{array}$ & $\begin{array}{l}\text { AGER, AIRE, ALDH3B1, ANK1, APLN, ARNT, } \\
\text { ATP7B, BBS2, BCAR1, BMP6, CACNA1A, } \\
\text { CADPS, CARD9, CCKBR, CCR8, CD48, CD5, } \\
\text { CDKN2C, CNR2, CTSD, DES, DKK3, DLK1, } \\
\text { ECEL1, EEF1A1, EFHC1, ELF4, F7, FAIM2, } \\
\text { FBLIM1, FGF6, GDF15, GPT, GRK1, H0RMAD1, } \\
\text { IL22, KCNIP1, KCNJ11, KDELR1, KLF1, LAMA5, } \\
\text { LGMN, LHB, LIF, LTB, MAGED1, MAPK13, } \\
\text { MCAM, MPG, MST1R, NEK6, NIF3L1, NLRP3, } \\
\text { N0S1, NPHP4, NR0B2, PAK4, PGR, PITX2, } \\
\text { PLEC }\end{array}$ & POLR2A \\
\hline & & Hypomethylated & $\begin{array}{l}\text { ADH5, AD0RA2B, AKAP8, ANGPT1, } \\
\text { ATF1, ATG10, TP6AP2, BCAP29, } \\
\text { BUB1B, CTSB, EN01, GAS2, } \\
\text { GRM3, HSPB11, IL5RA, IQUB, } \\
\text { IRAK3, ISG15, MAP3K3, NSF, } \\
\text { 0GDH, PDPK1, PEBP1, PPP1R9A, } \\
\text { PPP2R1B, PRNP, RAP1A, RCHY1, } \\
\text { SLC1A1, SPRY2, STC1, TAC1, } \\
\text { TCEB1, TFPI2, TMEM14A, } \\
\text { TRMT11, ZC3H8 }\end{array}$ & CFB, PARP16, RNASEL, TFDP2 & $\begin{array}{l}\text { ABL1, ARL6IP1, BLOC1S2, BTG3, } \\
\text { CDC25A, CDCA2, CENPA, CRBN, } \\
\text { EBF1, F0S, GCLM, GNAI3, GPX7, } \\
\text { GRIA2, GSK3A, ID01, IGF1, IKZF2, } \\
\text { IL1B, LIG4, MAP2K6, MNAT1, } \\
\text { MRPS30, NR3C1, PHLDA1, } \\
\text { PPARGC1A, RNF19A, RRAS2, } \\
\text { SEC23B, SHC3, SLC11A2, TAF1B, } \\
\text { TANK, TOPBP1 }\end{array}$ \\
\hline
\end{tabular}

We first examined the effect of short and prolonged withdrawal on mRNA levels. We found a transcriptional response in 903 genes after early withdrawal (comparison of transcriptomes between $1 \mathrm{~W}$-Sal, moderated $t$ test, $p<0.05$ ), which was similar to the number of genes that showed a transcriptional response after prolonged withdrawal (comparison of transcriptomes between $30 \mathrm{~W}-1 \mathrm{~W}=922$ genes, moderated $t$ test, $p<0.05$; Table 4$)$. It is notable that, as opposed to the result for transcriptional response, above we found a time-dependent increase in the DNA methylation response.

We next determined changes in mRNA expression after "incubated" (late withdrawal) or "nonincubated" (early withdrawal) cue-induced cocaine seeking. The transcriptome of rats after extinction responding on day 1 or day 30 was compared with the transcriptome on the respective day of withdrawal (1C-1W or 30C-30W). Interestingly, similar to the findings for DNA methylation, "incubated" and "nonincubated" cueinduced cocaine seeking reversed part of the expression changes triggered by the corresponding withdrawal periods, as shown by the inverse correlations between expression levels at withdrawal and extinction (1C-1W vs $1 \mathrm{~W}-\mathrm{Sal}: r=-0.14, p=0.03$; 30C$30 \mathrm{~W}$ vs $\left.30 \mathrm{~W}-1 \mathrm{~W}: r=-0.4, p=2.20 \mathrm{E}^{-11}\right)$.

\section{Association between DNA methylation and transcription changes}

Next, we examined the relationship between changes in DNA methylation and in mRNA expression observed after the withdrawal periods and subsequent extinction tests. 

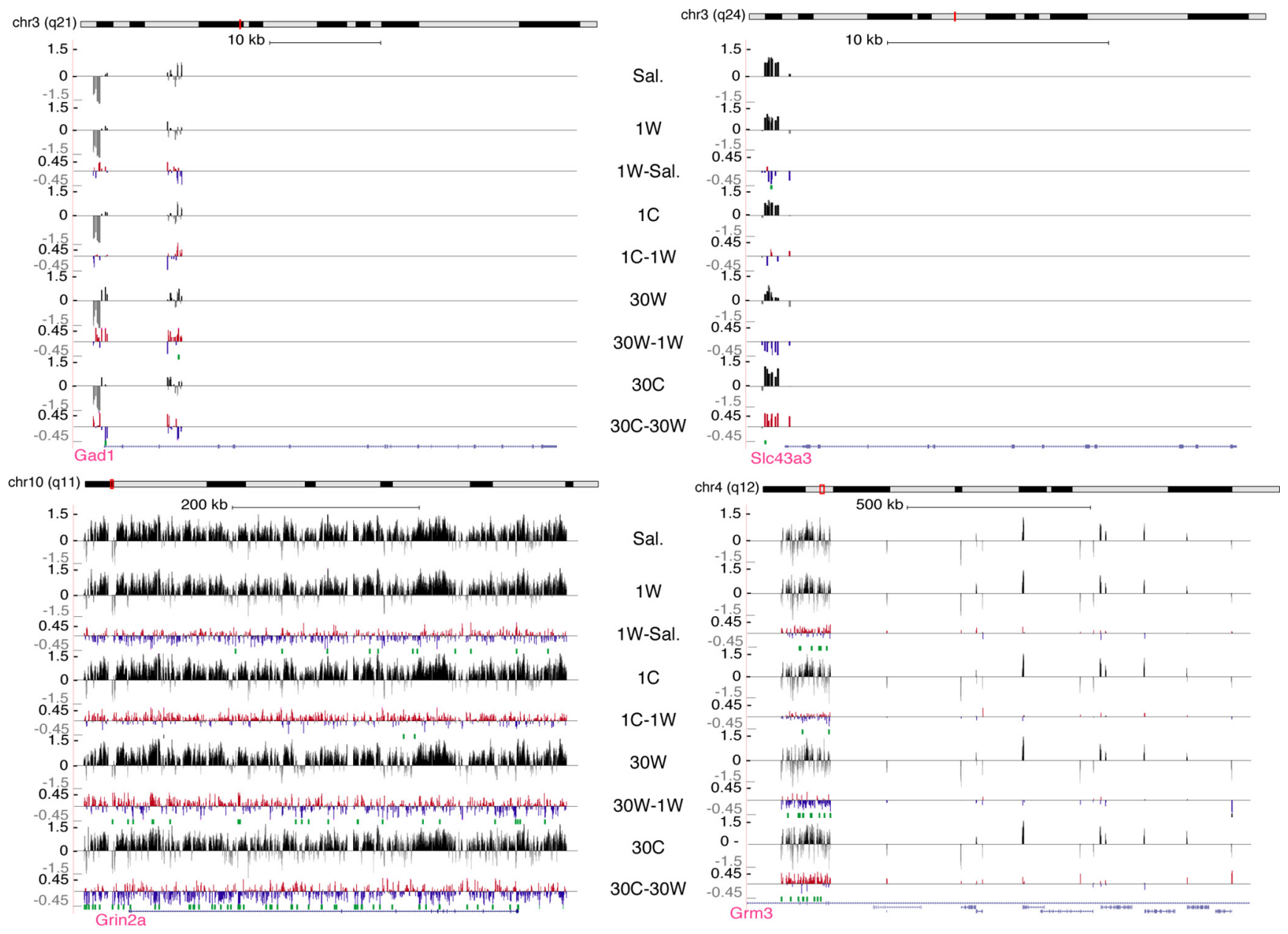

Figure 3. Illustration of DNA methylation changes of GAD1 and s/ $433 a 3$ promoters and of Grin2a and Grm3 genes. Expanded views of DNA methylation patterns for sample gene loci, visualized using the UCSC genome browser: GAD1 (glutamate decarboxylase 1), slc43a3 (solute carrier family 43, member 3), Grin2a (glutamate receptor, ionotropic, N-methyl D-aspartate 2A), and Grm3 (glutamate receptor metabotropic 3). For each gene, the tracks 1, 2, 4, 6, and 8 show the average methylation intensities of the saline, 1W (day 1 withdrawal), 1C (day 1 cue), $30 \mathrm{~W}$ (day 30 withdrawal), and $30 \mathrm{C}$ (day 30 cue) conditions, respectively, measured using MeDIP microarrays. The tracks 3, 5, 7, and 9 show average methylation probe fold differences (Log2) between experimental conditions. Green dots represent regions significantly differentially methylated corresponding to the above differential track. An individual probe was considered differentially methylated if the significance of its $t$-statistic was at most 0.01 and the associated difference of means between the groups was at least 0.5 . We calculated the significance of enrichment for highor low-probet-statistics of all probes within each gene promoter. Significance was determined using the Wilcoxon rank-sum test comparing $t$-statistics of these probes against those of all the probes on the microarray. A gene promoter was then considered differentially methylated if its FDR was at most 0.2 and if one of its probes was considered differentially methylated. Grm 3 shows inversion of its methylation state after prolonged withdrawal, s/c43a3 and Grin2a show enhanced methylation, and GAD1 shows newly methylated regions after prolonged withdrawal. Cue-induced cocaine seeking generally caused the reversal of methylation changes observed during withdrawal. The last track shows exons and introns based on the rat NCBI RNA reference sequences collection (RefSeq).

Table 4. Number of genes differentially expressed under the various experimental conditions $^{a}$

\begin{tabular}{|c|c|c|}
\hline & Upregulated & Downregulated \\
\hline Early changes (1W-Sal) ${ }^{b}$ & 202 & 701 \\
\hline Effect of cue compared with early changes $(1 C-1 W)^{c}$ & 315 & 148 \\
\hline Withdrawal changes $(30 \mathrm{~W}-1 \mathrm{~W})^{d}$ & 739 & 183 \\
\hline Effect of cue compared with late changes $(30 \mathrm{C}-30 \mathrm{~W})^{e}$ & 295 & 230 \\
\hline
\end{tabular}

$\overline{a_{p}<0.05 \text {. }}$

${ }^{b}$ Rats after $1 \mathrm{~d}$ of cocaine withdrawal (W) compared with rats after $1 \mathrm{~d}$ of saline "withdrawal."

'Rats tested for extinction responding (cue-induced cocaine seeking [C]) at day 1 compared with day 1 withdrawal. ${ }^{d}$ Rats after $30 \mathrm{~d}$ withdrawal compared with $1 \mathrm{~d}$ withdrawal.

${ }^{e}$ Rats tested for extinction responding on day 30 compared with day 30 withdrawal.

We found a small, though significant, number of genes that were both differentially methylated $(p<0.05$, FDR $<0.2)$ and expressed $(p<0.05)$ after $1 \mathrm{~d}$ of withdrawal (1W-Sal; 38 genes, $p=7.3 \mathrm{E}^{-7}$, hypergeometric test) or $30 \mathrm{~d}$ of withdrawal (30W$1 \mathrm{~W} ; 145$ genes, $p=4.8 \mathrm{E}^{-4}$, hypergeometric test). This relatively small number of genes is in accord with the indirect and complex relationship between DNA methylation, which defines transcriptional competence of a gene, and steady-state mRNA levels, a product of numerous post-transcriptional processes as well as transcription initiation (Molloy and Watt, 1990; Tate and Bird, 1993; Adam et al., 2001; Coleman-Derr and Zilberman, 2012; Kulis et al., 2013).

The corresponding differences in methylation and in expression of several of these genes were further confirmed by MeDIP-qPCR and qRT-PCR (Fig. 4A; Student's unpaired $t$ tests; $1 \mathrm{~W}$ vs Sal and $30 \mathrm{~W}$ vs $1 \mathrm{~W}$, showing significance between groups, $p<0.05$; followed by Welch's correction; $p<0.05$, $p<0.01)$. Based on the qPCR results, we observed a significant negative correlation between methylation enrichment at promoters of these genes and mRNA expression levels $(r=0.83$, $p<0.0001$; Fig. $4 B$ ). Indeed, at both early and late withdrawal, changes in DNA methylation were negatively correlated with changes in gene expression (for genes that became differen- 

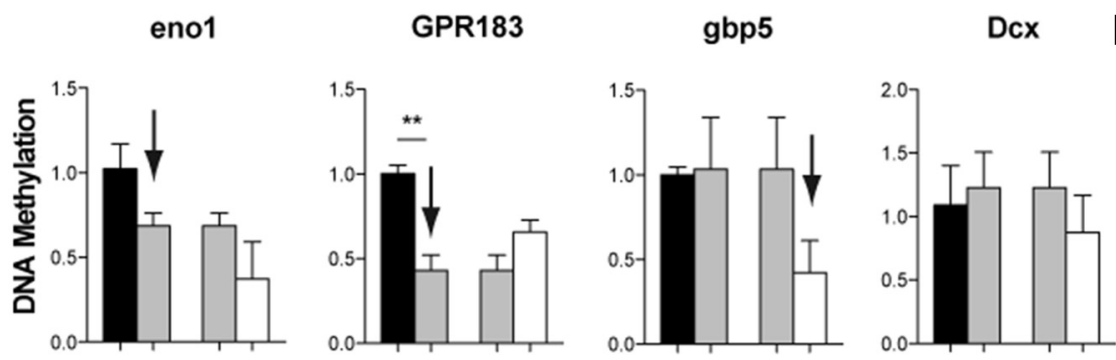

B
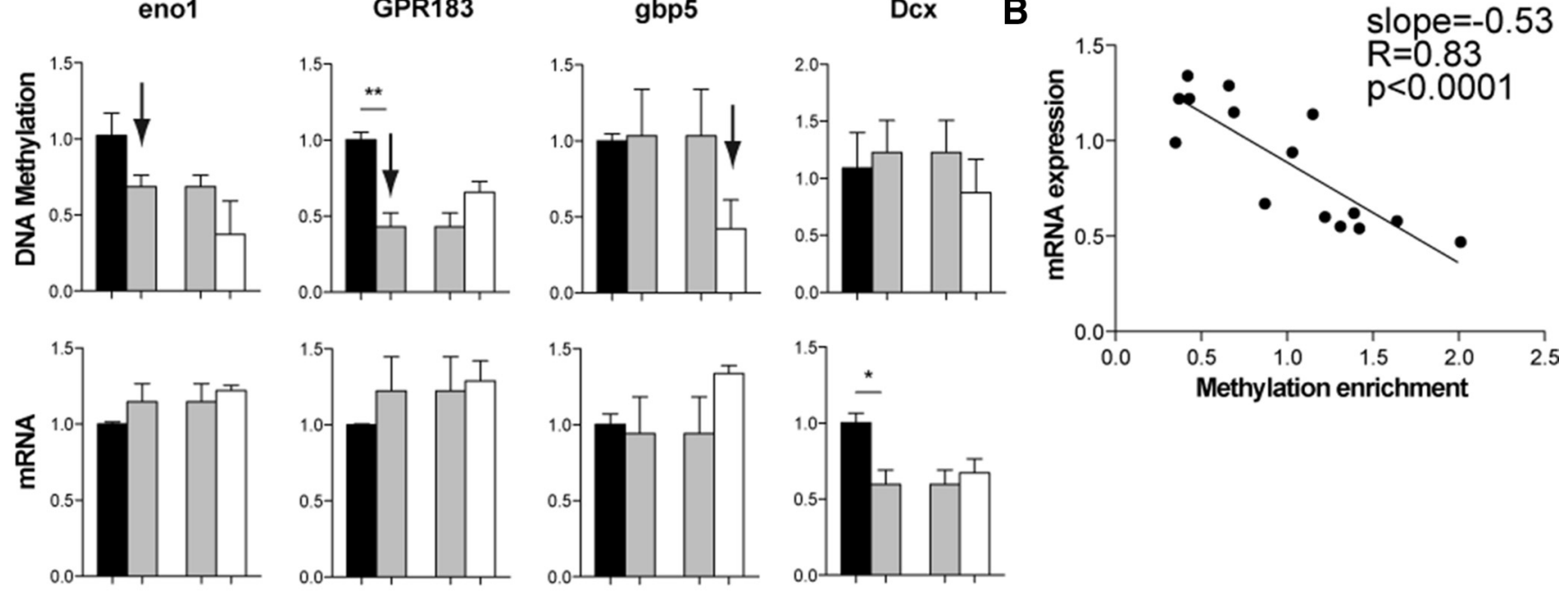

Methylation enrichment
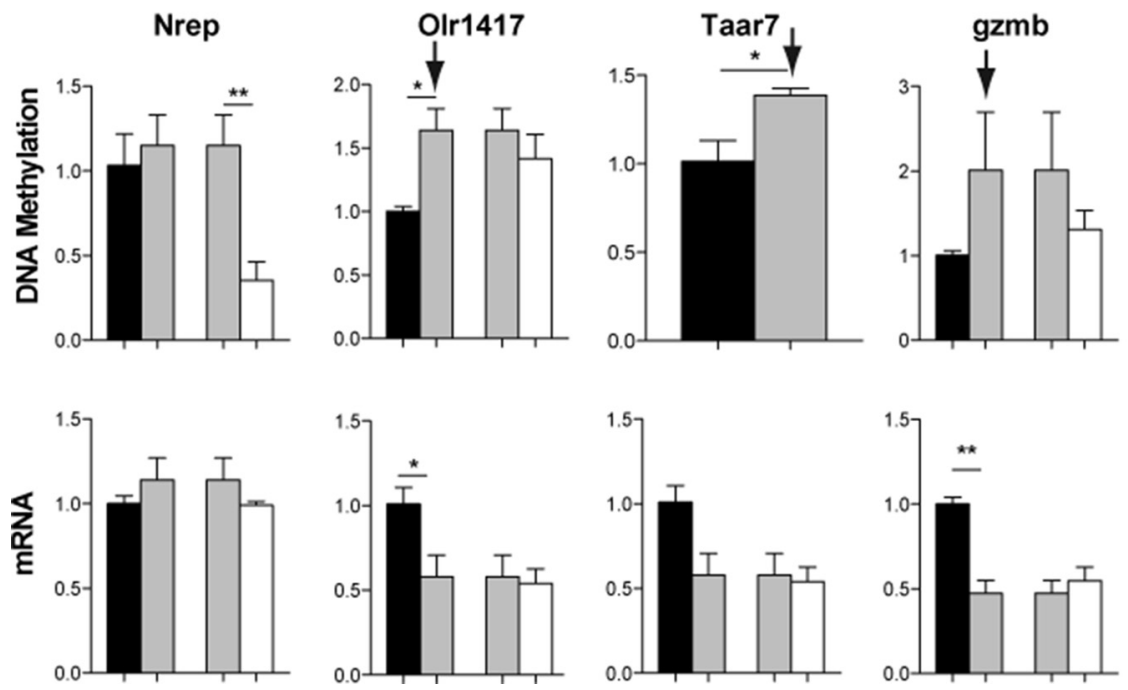

Figure 4. Correlation between DNA methylation and mRNA expression changes after withdrawal and cue-induced cocaine seeking. $A, q P C R$ validations of MeDIP arrays and mRNA arrays after withdrawal. Each bar plot indicates average methylation or mRNA expression levels ( \pm SEM) for 3 pools of rats, each consisting of triplicates of 2 or 3 rats. Student's unpaired $t$ tests were performed ( $1 \mathrm{~W}$ vs Sal and $30 \mathrm{~W}$ vs $1 \mathrm{~W}$ ), followed by Welch's correction when variances between groups were significantly different. ${ }^{*} p<0.05 .{ }^{* *} p<0.01$. Arrows indicate conditions for which inverse correlations between changes in DNA methylation and expression were observed. $\boldsymbol{B}$, Inverse correlation between methylation and expression changes based on $\mathrm{qPCR}$ results of $\boldsymbol{A}$.

tially methylated at $1 \mathrm{~W}-\mathrm{Sal}: r=-0.22, p=4.27 \mathrm{E}^{-10}$; for genes that changed methylation between $30 \mathrm{~W}-1 \mathrm{~W}: r=-0.3$, $p=6.03 \mathrm{E}^{-48}$ ).

For the 47 candidate genes, methylation and expression differences were mostly negatively correlated, except Gabrd for which they were positively correlated.

We next examined whether changes in DNA methylation in response to withdrawal poise the genes to be induced or repressed by cue-induced cocaine seeking, rather than affect steady-state levels of expression. Indeed, whereas DNA methylation is thought to be responsible for gene expression programming, expression is triggered by transient exposures to external signals. Thus, when steady-state expression is measured in the absence of a trigger, no differences are observed between methylated and unmethylated genes. However, upon stimulation, demethylated genes respond with enhanced transcription. The most established examples are hormones such as glucocorticoids (Thomassin et al., 2001). We believe that this is especially important in a highly signal- and context-sensitive tissue as the brain. Therefore, we tested whether the cue might be a similar signal and trigger expression changes in genes that were programmed by DNA methylation during withdrawal. We found that 68 genes whose DNA methylation states after prolonged withdrawal were different from after early withdrawal (30W-1W), underwent changes in expression only in response to the cue (30C-30W).

\section{Effect of modulation of NAc DNA methylation on cue-} induced cocaine seeking after prolonged withdrawal

The broad dynamic changes in DNA methylation observed after the 30 day withdrawal from cocaine, and following extinction responding at day 30 , raised the question whether it is possible to affect "incubated" cue-induced craving by modulating DNA 

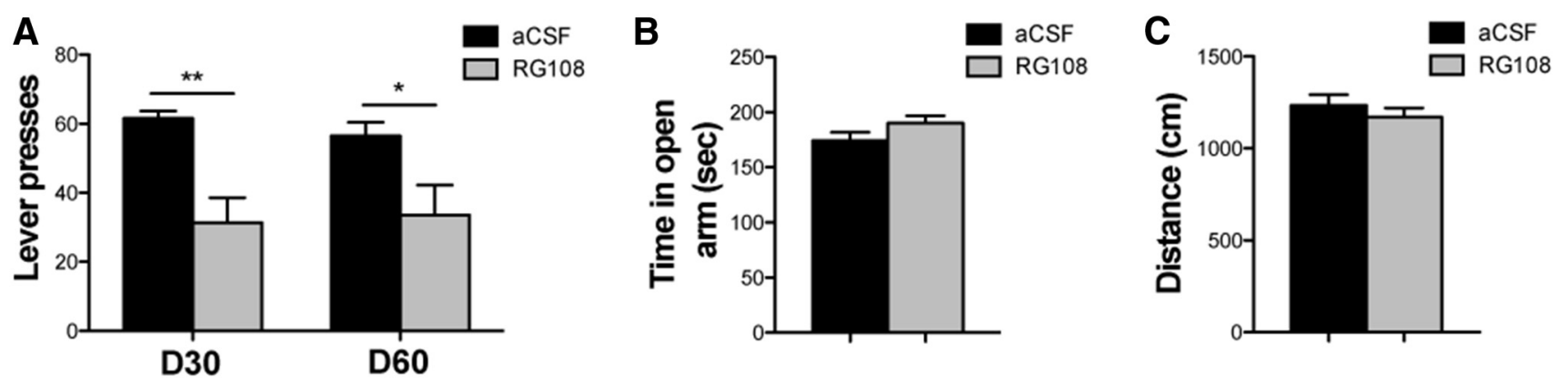

D

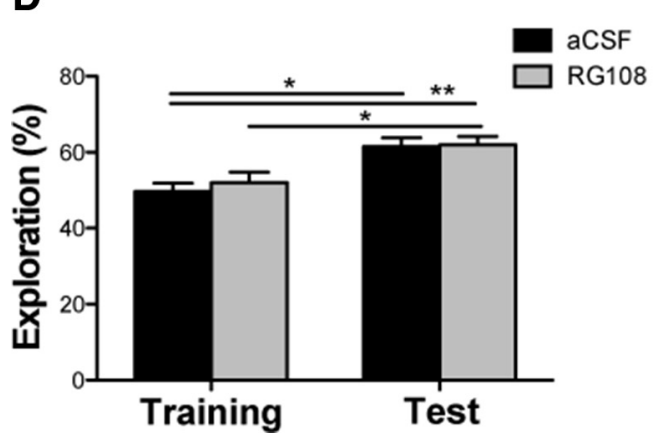

E

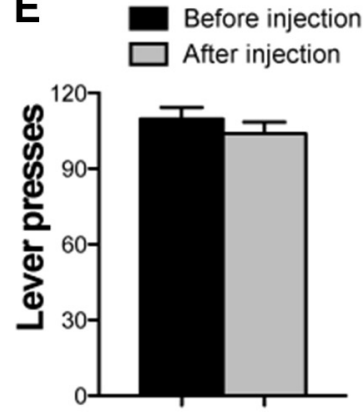

$\mathbf{F}$

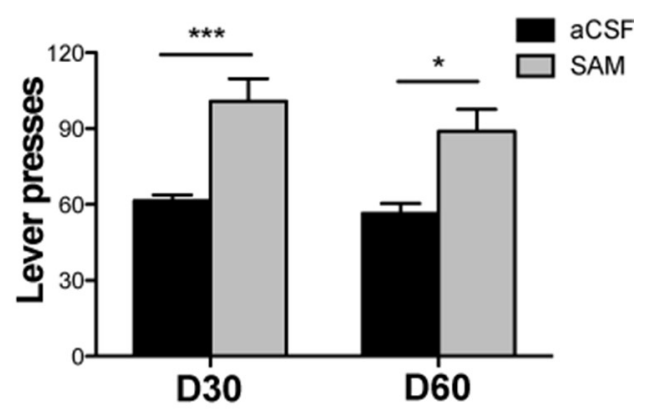

Figure 5. Modulation of cue-induced cocaine seeking by intra-NAc injections of RG108 or SAM. Rats trained for cocaine self-administration were withdrawn for $30 \mathrm{~d}$ and then treated with intra-NAc injections of either RG108, SAM, or aCSF. Extinction responding was assessed at day 30 and 1 month later at day 60 . $A$, The mean number of active lever presses in RG108-treated rats $(n=$ 16) was significantly lower than in aCSF-treated rats $(n=13)$, on day 30 and on day $60 .{ }^{*} p<0.05$ (one-way ANOVA followed by Student-Newman-Keuls' test). ${ }^{* *} p<0.01$ (one-way ANOVA followed by Student-Newman-Keuls' test). The number of inactive lever presses for treatment and control groups was $<13 \%$ (day 30 ) or $18 \%$ (day 60 ) of active lever presses of controls, and not significantly different between groups (day 30:5.7 \pm 2.3 for RG108 vs $8.6 \pm 3.6$ for control; day $60: 6.1 \pm 1.7$ for RG108 vs $11.2 \pm 1.9$ for control; $p>0.05$, Student's $t$ test). $\boldsymbol{B}-\boldsymbol{D}$, Following the extinction test, RG108-treated rats underwent a series of behavioral experiments. $\boldsymbol{B}$, Elevated plus maze: No difference was found between RG108-treated rats and controls in time spent in the open arms of the maze. C, Locomotion test: Rats were placed in the open field arena for $5 \mathrm{~min}$. No difference was found between RG108-treated rats and controls in total distance moved (cm). D, 0bject recognition test: Rats were placed in the open field arena with two similar objects for the training session and a new object $24 \mathrm{~h}$ later for the testing session. Rats from both groups showed preference for the new object during the test phase. ${ }^{*} p<0.05$, versus the corresponding phase (two-way ANOVA followed by Student-Newman-Keuls' test). But there was no difference between RG108-treated and control groups in time spent to explore the new object. $E$, Effect of RG108 on lever response during training: After 8 days of cocaine self-administration training, rats received intra-NAc injection of RG108. The number of active lever presses was not significantly different before and after injection ( $p=0.12$, one-way ANOVA with repeated measures). $\boldsymbol{F}$, The mean number of active lever presses was significantly higher in SAM-treated rats $(n=13)$ compared with aCSF-treated rats $(n=13)$, on day 30 and day $60 .{ }^{*} p<0.05$. ${ }^{* * *} p<0.001$ (one-way ANOVA followed by Student-Newman-Keuls' test). For all graphs, data are mean \pm SEM. The number of inactive lever presses for both treatment and control groups was $<13 \%-16 \%$ of active lever presses in corresponding groups, and not significantly different between groups (day 30:9.4 \pm 4.2 for SAM vs $10.3 \pm 3.4$ for control; day 60: 7.5 \pm 2.9 for SAM vs $8.2 \pm 1.8$ for control; $p>0.05$, Student's $t$ test).

methylation. Therefore, rats were trained to self-administer cocaine $(0.75 \mathrm{mg} / \mathrm{kg}, 6 \mathrm{~h} / \mathrm{d}$ for $10 \mathrm{~d})$ and subjected to $30 \mathrm{~d}$ of withdrawal. On day 29 and day 30, rats received intra-NAc injections of a DNMT inhibitor (RG108, $100 \mu \mathrm{M})$, a methyl donor (SAM, $500 \mu \mathrm{M}$ ), or aCSF as control (Fig. 1A). We found a significant decrease in the number of active lever presses of RG108-treated rats compared with aCSF-injected rats during the extinction test (day 30); this effect endured up to 1 month after the single RG108 treatment (day 60) (one-way ANOVA main effect of group: $F_{(2,20)}=6.4 ; p=0.0032$ followed by Student-Newman-Keuls' test; $p<0.01$ for day $30, p<0.05$ for day 60 ; Fig. $5 A$ ).

Examination of nonspecific confounders showed that intra-NAc RG108 injected on day 30 had no effect on stress- and anxiety-related behaviors (examined using the elevated plus maze; $p>0.05$; Fig. $5 B$ ), physical performance (using the open field test; $p>0.05$; Fig. $5 C$ ), or memory (using the object recognition test; RG108-treated and controls both showed preference for new object, two-way ANOVA main effect of phase: $F_{(1,19)}=20.68 p<0.0002$, StudentNewman-Keuls' $p<0.05, p<0.01$ for test phase vs training; $p>$ 0.05 for time spent to explore new object, control vs treated). Furthermore, there was no significant difference between the number of active lever pressing before and after an intra-NAc injection of RG108 on day 8 of self-administration training (one-way ANOVA with repeated measures, $F_{(5,24)}=2.82, p=0.12$; Figs. $1 B$ and $5 E$ ).
These findings suggest that a single RG108 exposure, rather than having acute and nonspecific effects on responding, has a specific, long-lasting effect on cue-induced cocaine seeking, possibly by long-term epigenetic reprogramming.

In contrast to the effect of RG108, treatment with SAM caused a significant increase in active lever pressing during the extinction test (day 30) compared with aCSF-treated rats; this effect remained up to 1 month after the single SAM treatment (day 60) (one-way ANOVA main effect of group: $F_{(2,19)}=9.37 ; p=$ 0.0005 , Student-Newman-Keuls' test; $p<0.001$ for day 30 and $p<0.05$ for day 60 ; Fig. $5 F$ ).

Together, our results imply that dynamic DNA methylation in the NAc is essential to "incubated" cue-induced cocaine seeking. Consistent with this hypothesis, we found that 3118 genes were differentially methylated in SAM-treated rats compared with aCSF-treated controls ( $p<0.01$, FDR $<0.2)$, after day 30 cueinduced cocaine seeking (Table 2). A gene set enrichment analysis revealed that these genes have predicted upstream regulators, such as progesterone $\left(p=2.43 \mathrm{E}^{-4}\right)$, estrogen $\left(p=1.2 \mathrm{E}^{-3}\right)$, L-DOPA $\left(p=6.63 \mathrm{E}^{-4}\right)$, FOSB $\left(p=6.15 \mathrm{E}^{-3}\right)$, CREM $(p=$ $\left.6.33 \mathrm{E}^{-3}\right)$, NR3C1 $\left(p=7.66 \mathrm{E}^{-3}\right)$, or cocaine $\left(p=8.94 \mathrm{E}^{-3}\right)$. For several genes, we used qPCR validations of MeDIP arrays to identify methylation differences between RG108, SAM, and control groups (one-way ANOVA showing significance of $p<0.05$ was 
A
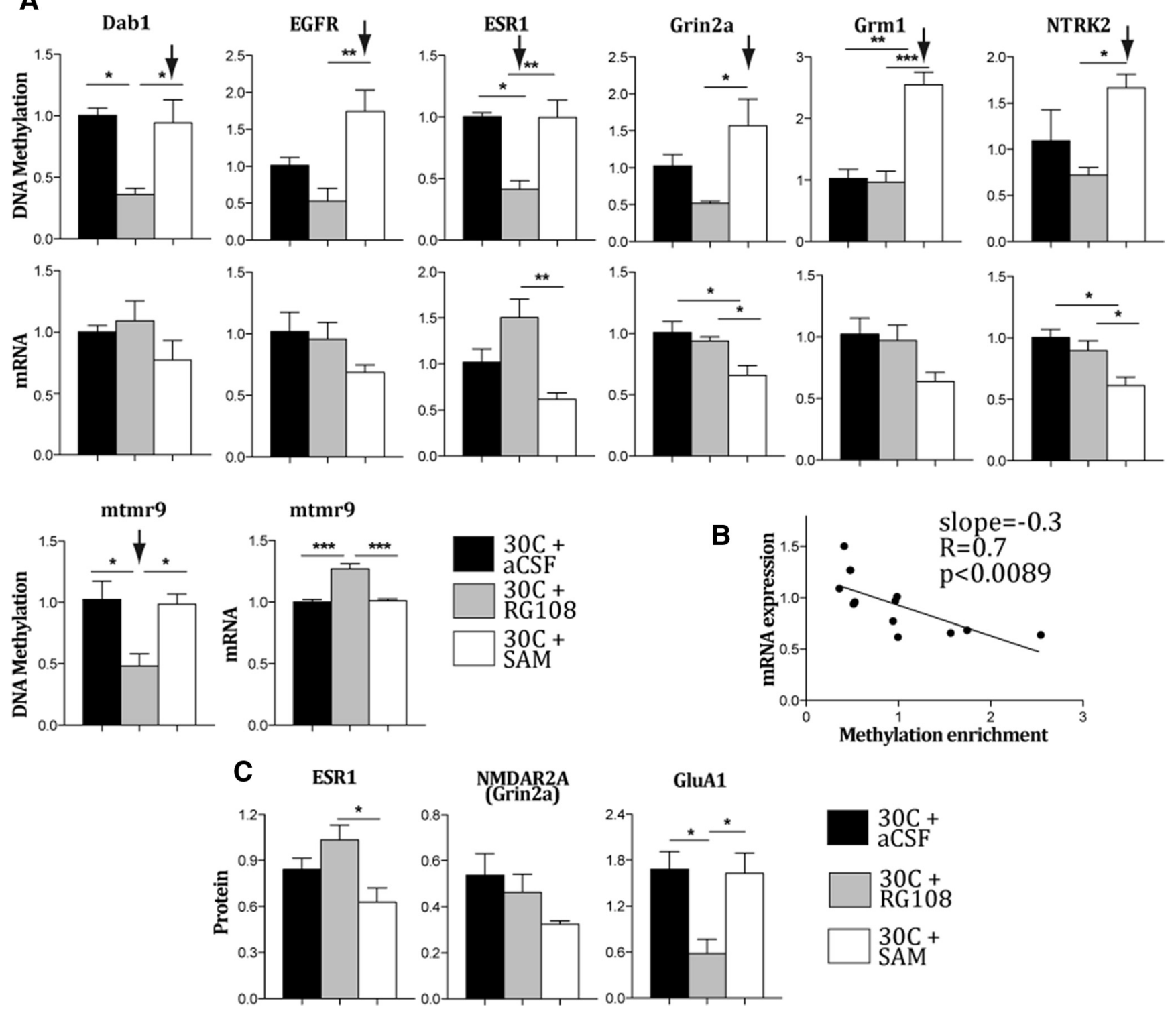

Figure 6. Modulation of DNA methylation, mRNA expression, and protein profiles by intra-NAc injections of RG108 or SAM. A, qPCR validations of MeDIP arrays identified methylation differences between treatment groups. Bar plots indicate average levels per group; $n=3$ or 4 per group. When the one-way ANOVA test was statistically significant $(p<0.05)$, Student-Newman-Keuls' post hoc was applied. ${ }^{*} p<0.05$. ${ }^{* *} p<0.01 ;{ }^{* * *} p<0.001$. Arrows indicate conditions for which inverse correlations were observed between DNA methylation and expression changes. $\boldsymbol{B}$, Inverse correlation between DNA methylation and expression changes based on results of $\boldsymbol{A}$. $C$, Changes in protein levels. Plotted are integrated density levels, normalized over histone $2 B$ protein levels (one-way ANOVA followed by Student-Newman-Keuls' test). ${ }^{*} p<0.05$.

followed by Student-Newman-Keuls' post hoc, $p<0.05$ and $p<$ 0.01 ; Fig. $6 A$ ), and obtained a positive correlation between qPCR and array quantifications. We also confirmed by qPCR that these DNA methylation differences triggered by RG108 or SAM are associated with mRNA expression changes (Fig. 6A), and demonstrated a significant negative correlation between DNA methylation and expression $(r=-0.7, p<0.0089$; Fig. $6 B$ ).

We next chose three genes previously associated with cocainerelated behavior or craving (Hemby et al., 2005; Renthal et al., 2009; Lasek et al., 2011; Loweth et al., 2014) and analyzed their differential protein levels in RG108-treated or SAM-treated rats. A near-significant decrease in NMDAR2A (Grin2a) levels was observed in SAM-treated rats. This decrease was parallel to a significant increase in Grin2a methylation (one-way ANOVA main effect of group: $F_{(2,8)}=5.134 ; p=0.0368$ followed by
Student-Newman-Keuls' test; $p<0.05$ for RG108 vs SAM; Fig. $6 A$ ) and significant decrease in Grin2a mRNA levels (one-way ANOVA main effect of group: $F_{(2,8)}=7.3 ; p=0.0157$ followed by Student-Newman-Keuls' test; $p<0.05$ for aCSF vs SAM and RG108 vs SAM; Fig. 6A). Treatment with RG108 induced a significant increase in estrogen receptor esrl protein levels (one-way ANOVA: $F_{(2,9)}=5.48 ; p=0.03$, Student-Newman-Keuls' test, $p<0.05$ compared with SAM; Fig. $6 C$ ), in addition to increased mRNA levels (one-way ANOVA main effect of group: $F_{(2,8)}=$ 9.323; $p=0.0081$ followed by Student-Newman-Keuls' test; $p<$ 0.01 for RG108 vs SAM; Fig. $6 A$ ) and decreased methylation levels (one-way ANOVA main effect of group: $F_{(2,8)}=11.07 ; p=0.005$ followed by Student-Newman-Keuls' test; $p<0.05$ for aCSF vs RG108 and $p<0.01$ for RG108 vs SAM; Fig. 6A). Examination of GluA1 (Grial) levels in RG108-treated rats showed a significant decrease compared with both aCSF and SAM treatments (one- 


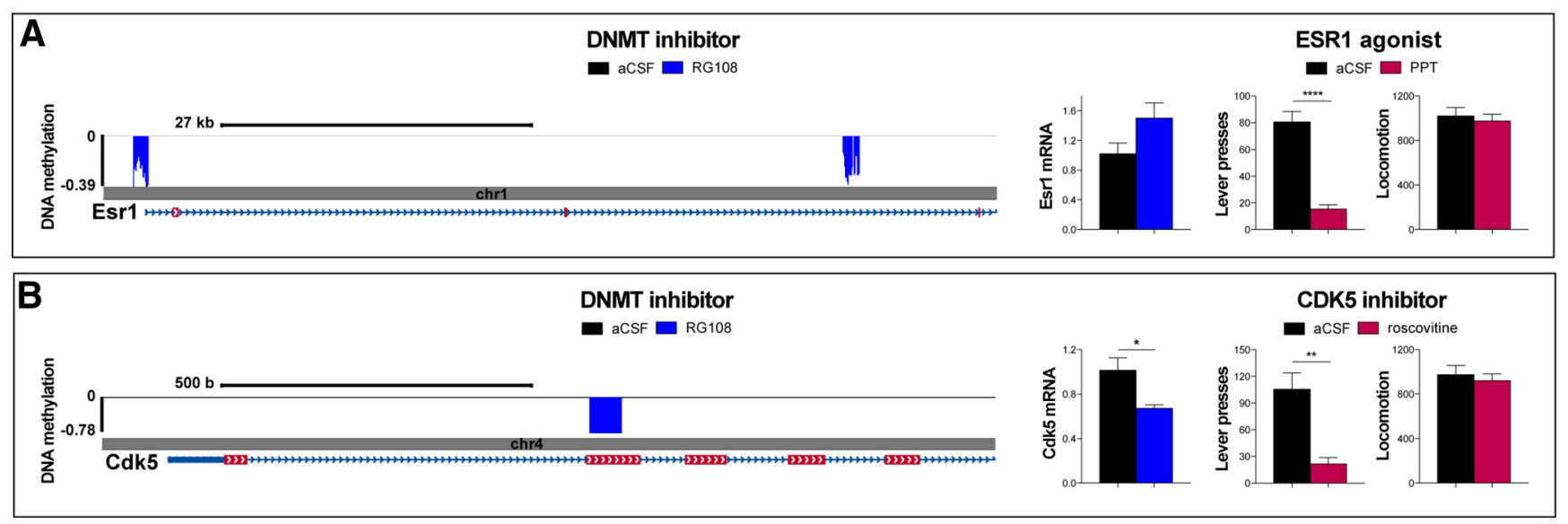

C

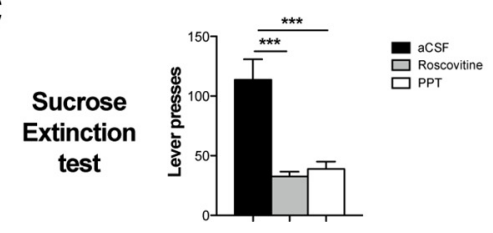

Figure 7. Cue-induced cocaine- or sucrose-seeking after intra-NAc injection of the ESR1 agonist PPT or the CDK5 inhibitor roscovitine. Tracks represent significant methylation probe fold differences (Log 2) between RG108-treated and aCSF-injected animals, as determined by MeDIP analysis for the esr 1 ( $\boldsymbol{A}$ ) and cdk5 (B) genes (the 3 and 5 first exons are shown in red for esr 1 and c $d k 5$, respectively). esr 1 and cdk5 mRNA levels after RG108 treatment are displayed (results identical to Fig. 6A). $\boldsymbol{A}, \boldsymbol{B}$, Rats were trained for cocaine self-administration, and on days 29 and $30 \mathrm{~d}$ withdrawal received intra-NAc injections of PPT (an ESR1 agonist) or roscovitine (a CDK5 inhibitor). During the extinction test on day 30, PPT-treated $(\boldsymbol{A})$ and roscovitine-treated ( $\boldsymbol{B})$ rats showed a decrease in the mean number of active lever presses ( \pm SEM). ${ }^{* * * *} p<0.0001$ (Student's $t$ test; PPT, $n=4$ per group). ${ }^{* *} p=0.0027$ (Student's $t$ test; roscovitine, $n=6$ per group). Both treatments significantly affected the number of active lever presses, whereas no change in active lever presses was observed in the corresponding control groups. The number of inactive lever presses for treatment and control groups was $<7 \%$ of active lever presses of controls, and not significantly different between groups ( $3.7 \pm 1.5$ for roscovitine vs $6.6 \pm 1.5$ for aCSF, $2.5 \pm 0.6$ for PPT vs $4.8 \pm$ 1.4 for aCSF; $p>0.05$, Student's $t$ test). No difference in locomotion was found for PPT-treated (A) or roscovitine-treated rats $(\boldsymbol{B})$, compared with aCSF-treated rats. $\boldsymbol{C}$, Rats were trained for self-administration of sucrose $(10 \% ; 0.13 \mathrm{ml} /$ infusion, $3 \mathrm{~h} / \mathrm{d}, 10 \mathrm{~d})$, and on day 21 of withdrawal received intra-NAc PPT or roscovitine and were then subjected to an extinction test. PPT-treated and roscovitine-treated rats showed a decrease in the mean number of active lever presses $( \pm S E M)$ compared with aCSF-treated rats. ${ }^{* * *} p<0.001$ (one-way ANOVA followed by Student-NewmanKeuls' test). The number of inactive lever presses for treatment and control groups was $<10 \%$ of active lever presses of controls, and not significantly different between groups ( $4.9 \pm 0.8$ for roscovitine, $5 \pm 1.1$ for PPT, $10 \pm 3.9$ for control; $p>0.05$, Student's $t$ test).

way ANOVA: $F_{(2,9)}=7.33 ; p=0.01$, Student-Newman-Keuls' test, $p<0.05$; Fig. $6 C)$.

\section{Intra-NAc pharmacological manipulation of downstream targets of DNMT inhibition}

Our results raised the question whether RG108 blocks cueinduced cocaine seeking through demethylation and change in expression of specific genes that are critical for this behavioral phenotype. If so, the proteins encoded by these genes should be candidates for pharmacological modulation of "incubated" cueinduced cocaine seeking. To examine this, we focused on two genes, estrogen receptor-1 (esr1) and cyclin-dependent kinase 5 ( $c d k 5)$, and on their protein products. Previous studies show that knock-out of esr 1 in mice results in enhanced cocaine sensitization and a trend toward increased cocaine seeking in the place preference model, and that estrogen contributes to altered behavioral responses to cocaine (Lasek et al., 2011). Moreover, knockout of $C d k 5$ in the NAc facilitates cocaine-induced locomotor sensitization and conditioned place preference for cocaine (Benavides et al., 2007). Yet, to the best of our knowledge, ESR1 and CDK5 have not been previously associated with cocaine craving. Herein, we found that intra-NAc RG108 injection before cue-induced cocaine seeking on day 30 caused demethylation of the esrl promoter and activation of mRNA expression (Figs. 6A, C and 7A). We also found that $c d k 5$ exhibited dynamic changes in DNA methylation during withdrawal from cocaine (Fig. 2E). RG108 treatment also inhibited $c d k 5$ mRNA expression during cue-induced cocaine seeking compared with aCSF-treated controls (Student's $t$ test; $p<0.05$; Fig. $7 B$ ) and caused significant demethylation in the $c d k 5$ gene body (FDR $=$ 0.09; Fig. $7 B$ ), which has been associated with silencing of expression in contrast with promoter demethylation (Hellman and Chess, 2007).

Therefore, we next targeted the proteins encoded by these two genes. Rats were trained to self-administer cocaine $(0.75 \mathrm{mg} / \mathrm{kg}, 6$ $\mathrm{h} / \mathrm{d}$ for $10 \mathrm{~d}$ ), and on day 29 and 30 of withdrawal, received an intra-NAc injection of either PPT, an ESR1 agonist (10 nM), or roscovitine, a CDK inhibitor $(28 \mu \mathrm{M})$. We found that both PPT and roscovitine caused a dramatic decrease in the amount of active lever presses during the extinction test on day 30 (Student's $t$ test, $p<0.0001$ and $p=0.0027$, respectively), with no effect on locomotion ( $p>0.05$; Fig. $7 A, B)$.

Next, we examined whether the effect of intra-NAc PPT or roscovitine is specific to incubation of cocaine craving or whether these agents have a general effect on responding for cues or rewards. Therefore, we examined the effect of these agents on cue responding for natural reward after prolonged withdrawal. Rats were trained to self-administer sucrose ( $10 \%$ sucrose solution; $0.13 \mathrm{ml} /$ infusion; $3 \mathrm{~h} / \mathrm{d}, 10 \mathrm{~d}$ ); and after $21 \mathrm{~d}$ of withdrawal, they received an intra-NAc injection of either PPT (10 nM) or roscovitine $(28 \mu \mathrm{M})$ before the extinction test. We found that rats treated with PPT or roscovitine showed a significant decrease in active lever pressing during extinction testing, compared with aCSF-treated rats (one-way ANOVA: $F_{(2,16)}=$ $18.95 p<0.0001$, followed by Student-Newman-Keuls' test, $p<0.001$; Fig. 7C). 
These results suggest that ESR1 and CDK5 play an important role in incubation of craving after withdrawal from both drug and natural rewards.

\section{Discussion}

In the present study, we show broad, dynamic, and timedependent increases in DNA methylation alterations in the NAc after cocaine withdrawal and cue-induced cocaine seeking. These methylation changes occurred in gene promoters at the wholegenome level and in selected candidate genes related to drug addiction and were partly negatively correlated to gene expression changes. DNMT inhibition by intra-NAc injection of RG108 significantly attenuated cue-induced cocaine seeking after prolonged withdrawal and up to 1 month after treatment, whereas the methyl donor SAM had the opposite effect, inducing a longterm increase in cue-induced cocaine seeking. Moreover, pharmacological targeting of ESR1 and CDK5, two proteins encoded by genes that were demethylated by RG108 treatment, significantly decreased cue-induced cocaine seeking. These results demonstrate a role for NAc DNA methylation, and downstream targets of DNA demethylation, in incubation of cocaine craving.

\section{DNA methylation alterations in the NAc in incubation of cocaine craving}

Previous evidence has shown that cocaine exposure affects DNA methylation. Maternal cocaine administration leads to altered global patterns of DNA methylation in the hippocampus of the offspring mice (Novikova et al., 2008). Acute cocaine administration leads to an increase in DNA methylation and an increase in the expression of DNMT3A and DNMT3B in the NAc (Anier et al., 2010), and chronic cocaine injections regulate DNMT3a expression in mouse NAc (LaPlant et al., 2010).

The prolonged period of withdrawal that follows extendedaccess cocaine self-administration results in "incubated," or heightened, craving (Pickens et al., 2011), indicating that withdrawal plays an active role in the development of the behavioral phenotype. Numerous electrophysiological, neuropharmacological, and molecular studies have shown that several molecular mechanisms and mesolimbic brain regions, including the NAc, play a role in incubation of cocaine craving. We have previously shown that $\beta$-endorphin release in the NAc, via the $\delta$ receptor, is involved in this phenomenon (Dikshtein et al., 2013). Others have shown that the expression of incubation after prolonged withdrawal is mediated by calcium-permeable AMPA receptors that accumulate at excitatory synapses onto medium spiny neurons of the NAc (Conrad et al., 2008; Mameli et al., 2009; Loweth et al., 2014). Scheyer et al. (2014) demonstrated that this accumulation and other "incubated" adaptations in glutamatergic transmission onto medium spiny neurons of the NAc require ongoing protein translation. Grimm et al. (2003) showed timedependent increases in BDNF protein levels in the NAc and other mesolimbic regions after cocaine withdrawal. Li et al. (2013) recently showed that BDNF transmission in the NAc core has a suppressive effect on cocaine seeking in early withdrawal, whereas late increases of BDNF protein in NAc shell contribute to incubation in late withdrawal. Silent synapse-based reorganization of the amygdala-to-NAc projection was shown to be critical for incubation of cocaine craving (Lee et al., 2013). In the present study, we show, for the first time, that incubation of cocaine craving is associated with extensive DNA methylation modifications in the NAc. Enrichment analysis of the genes differentially methylated and expressed during withdrawal and cue-induced cocaine seeking, with or without the drug treatments, is consis- tent with previous evidence on involvement of these genes in cocaine craving and relapse. It is notable that DNA methylation changes occurred over the process of incubation of cocaine craving in the 47 candidate genes whose biological involvement in cocaine addiction has been well established, further supporting the hypothesis that DNA methylation is functionally involved in incubation of cocaine craving.

Our findings show that, although some early changes in DNA methylation persisted and were stable over the prolonged period of withdrawal, other early changes showed different types of dynamic alterations over this period. Moreover, many genes changed their methylation state only after prolonged withdrawal. Interestingly, both "incubated" and "nonincubated" cueinduced cocaine seeking also resulted in broad changes in DNA methylation, and the time-dependent increases in cue-induced cocaine craving after withdrawal correlated with time-dependent increases in epigenetic alterations. Furthermore, changes in DNA methylation during withdrawal and cue-induced cocaine seeking were overall correlated with changes in gene expression and/or translation. These results suggest the involvement of NAc DNA methylation alterations in incubation of cocaine craving.

It is notable that the alterations in the various genes during incubation of craving could also point to less-explored processes, such as inflammation, RNA splicing, or changes in steroid hormone levels. Our data suggest that the epigenetic changes involve altering outputs of complex networks, rather than a small number of proteins. Traditional single pathway analyses, by either single-gene or pharmacological knockdowns, would not capture the complexity of the rearrangement of genome function over the incubation process.

\section{Modulation of DNA methylation in the NAc alters "incubated" cue-induced cocaine seeking}

The finding that NAc DNA methylation changes evolve over the 30 day withdrawal period and show further change after cueinduced cocaine seeking at day 30 suggested that manipulation of DNA methylation could alter "incubated" cue responding. We demonstrated that the global DNMT inhibitor RG108 reduced, whereas the methyl donor SAM intensified, cue-induced cocaine seeking up to 1 month after treatment. These findings indicate that DNA methylation alterations are consequential for "incubated" cue-induced craving. Moreover, the effect of the single treatment with epigenetic modulators suggests that the DNA methylation pattern is dynamic at this point and that the longlasting effect may have occurred through reprogramming of the epigenetic consequences of withdrawal and the cocaineassociated cue.

It is notable that SAM and RG108 targeted a significant fraction of the group of genes that was altered by cue-induced cocaine seeking. Of particular interest is that RG108 treatment caused a significant decrease in GluA1 protein in the NAc. Prior studies have shown that upregulation of homomeric GluA1 receptors is necessary for expression of incubation of cocaine craving (Conrad et al., 2008; Mameli et al., 2009; Loweth et al., 2014), which may additionally account for the ability of RG108 to decrease craving.

Previous studies have shown that local knock-out or pharmacological inhibition of DNMT3a in the NAc promotes cocaine place conditioning and locomotor responses, with opposite effects seen upon DNMT3a overexpression (LaPlant et al., 2010). The seemingly opposite actions of DNA methylation highlight the importance of studying epigenetic mechanisms in a selfadministration model. Another study (Day et al., 2013) demon- 
strated that reward learning produced changes in DNA methylation at genes that were upregulated in dopamine neurons following learning and that DNA methylation inhibition in the VTA significantly reduced consolidation of long-term memory of sucrose cue-reward association only when applied during acquisition but did not alter previously formed associations. In contrast, they showed that DNA methylation inhibition in the NAc core before sucrose reward conditioning did not alter cuereward association. Our results show that DNA methylation inhibition in the NAc before retrieval of cocaine-associated memory (by exposure to the cocaine-associated cue in the extinction test) causes long-lasting attenuation of cue-induced cocaine seeking. This suggests that DNA methylation regulation of natural reward-related associative memory may be different from regulation of incubation of craving, for either cocaine or sucrose. Moreover, as our data suggest, cocaine-conditioned approach responses and heightened craving are probably not limited to the learning process but involve a more complex biological system and neuronal types that aim to cope with the progression of a stressful incentive salience.

\section{Downstream targets of DNA methylation inhibition are critical for "incubated" cue-induced cocaine seeking} We reasoned that RG108 inhibits "incubated" cue-induced cocaine craving through demethylation of target genes. Although several genes are affected by DNA methylation changes, we asked whether two of these genes, esr 1 and $c d k 5$, could each be critical on its own for incubation of craving. If so, the proteins encoded by these genes should be candidates for pharmacological modulation of cue-induced cocaine seeking after prolonged withdrawal. Both targets, ESR1 and CDK5, validated this approach (Fig. 7), further illustrating the causal role of DNA methylation alterations and their targets in incubation of cocaine craving.

Targeting of ESR 1 and CDK5 also decreased the expression of incubation of sucrose craving. This result is consistent with the work of Uejima et al. (2007) who showed that a mGluR(2/3) agonist, which prevented enhanced cue-induced cocaine seeking after prolonged withdrawal, was also effective in attenuating cueinduced sucrose seeking after prolonged withdrawal. Our findings suggest that the downstream targets of DNA methylation inhibition, ESR1 and CDK5, play a role in the incubation of reward craving after withdrawal from both drug and natural rewards.

In conclusion, our findings support the hypothesis that DNA methylation is functionally involved in incubation of cocaine craving and may also regulate specific genes involved in the development of the craving phenotype. Our data offer a new approach to elucidate mechanisms leading to cocaine craving and have possible implications for developing future treatment strategies.

\section{Notes}

Supplemental material for this article is available at http://www. medicine.mcgill.ca/pharma/mszyflab/Main.htm. This material has not been peer reviewed.

\section{References}

Adam M, Robert F, Larochelle M, Gaudreau L (2001) H2A.Z is required for global chromatin integrity and for recruitment of RNA polymerase II under specific conditions. Mol Cell Biol 21:6270-6279. CrossRef Medline

Anier K, Malinovskaja K, Aonurm-Helm A, Zharkovsky A, Kalda A (2010) DNA methylation regulates cocaine-induced behavioral sensitization in mice. Neuropsychopharmacology 35:2450-2461. CrossRef Medline
Basso AM, Spina M, Rivier J, Vale W, Koob GF (1999) Corticotropinreleasing factor antagonist attenuates the "anxiogenic-like" effect in the defensive burying paradigm but not in the elevated plus-maze following chronic cocaine in rats. Psychopharmacology 145:21-30. CrossRef Medline

Bedi G, Preston KL, Epstein DH, Heishman SJ, Marrone GF, Shaham Y, de Wit H (2011) Incubation of cue-induced cigarette craving during abstinence in human smokers. Biol Psychiatry 69:708-711. CrossRef Medline

Benavides DR, Quinn JJ, Zhong P, Hawasli AH, DiLeone RJ, Kansy JW, Olausson P, Yan Z, Taylor JR, Bibb JA (2007) Cdk5 modulates cocaine reward, motivation, and striatal neuron excitability. J Neurosci 27:1296712976. CrossRef Medline

Coleman-Derr D, Zilberman D (2012) DNA methylation, H2A.Z, and the regulation of constitutive expression. Cold Spring Harbor Symp Quant Biol 77:147-154. CrossRef Medline

Comb M, Goodman HM (1990) CpG methylation inhibits proenkephalin gene expression and binding of the transcription factor AP-2. Nucleic Acids Res 18:3975-3982. CrossRef Medline

Conrad KL, Tseng KY, Uejima JL, Reimers JM, Heng LJ, Shaham Y, Marinelli M, Wolf ME (2008) Formation of accumbens GluR2-lacking AMPA receptors mediates incubation of cocaine craving. Nature 454:118-121. CrossRef Medline

Contoreggi C, Lee MR, Chrousos G (2013) Addiction and corticotropinreleasing hormone type 1 receptor antagonist medications. Ann N Y Acad Sci 1282:107-118. CrossRef Medline

Day JJ, Childs D, Guzman-Karlsson MC, Kibe M, Moulden J, Song E, Tahir A, Sweatt JD (2013a) DNA methylation regulates associative reward learning. Nat Neurosci 16:1445-1452. CrossRef Medline

Deroche-Gamonet V, Sillaber I, Aouizerate B, Izawa R, Jaber M, Ghozland S, Kellendonk C, Le Moal M, Spanagel R, Schütz G, Tronche F, Piazza PV (2003) The glucocorticoid receptor as a potential target to reduce cocaine abuse. J Neurosci 23:4785-4790. Medline

Dikshtein Y, Barnea R, Kronfeld N, Lax E, Roth-Deri I, Friedman A, Gispan I, Elharrar E, Levy S, Ben-Tzion M, Yadid G (2013) Beta-endorphin via the $\delta$ opioid receptor is a major factor in the incubation of cocaine craving. Neuropsychopharmacology 38:2508-2514. CrossRef Medline

Feng MJ, Yan SE, Yan QS (2006) Cocaine exposure at a sublethal concentration downregulates CREB functions in cultured neuroblastoma cells. Brain Res 1077:59-66. CrossRef Medline

Gawin FH, Kleber HD (1986) Abstinence symptomatology and psychiatric diagnosis in cocaine abusers: clinical observations. Arch Gen Psychiatry 43:107-113. CrossRef Medline

Grimm JW, Hope BT, Wise RA, Shaham Y (2001) Neuroadaptation: incubation of cocaine craving after withdrawal. Nature 412:141-142. CrossRef Medline

Grimm JW, Lu L, Hayashi T, Hope BT, Su TP, Shaham Y (2003) Timedependent increases in brain-derived neurotrophic factor protein levels within the mesolimbic dopamine system after withdrawal from cocaine: implications for incubation of cocaine craving. J Neurosci 23:742-747. Medline

Hellman A, Chess A (2007) Gene body-specific methylation on the active X chromosome. Science 315:1141-1143. CrossRef Medline

Hemby SE, Horman B, Tang W (2005) Differential regulation of ionotropic glutamate receptor subunits following cocaine self-administration. Brain Res 1064:75-82. CrossRef Medline

Huang YH, Lin Y, Brown TE, Han MH, Saal DB, Neve RL, Zukin RS, Sorg BA, Nestler EJ, Malenka RC, Dong Y (2008) CREB modulates the functional output of nucleus accumbens neurons: a critical role of N-methyl-Daspartate glutamate receptor (NMDAR) receptors. J Biol Chem 283: 2751-2760. CrossRef Medline

Hunt WA, Barnett LW, Branch LG (1971) Relapse rates in addiction programs. J Clin Psychol 27:455-456. CrossRef Medline

Klengel T, Mehta D, Anacker C, Rex-Haffner M, Pruessner JC, Pariante CM, Pace TW, Mercer KB, Mayberg HS, Bradley B, Nemeroff CB, Holsboer F, Heim CM, Ressler KJ, Rein T, Binder EB (2013) Allele-specific FKBP5 DNA demethylation mediates gene-childhood trauma interactions. Nat Neurosci 16:33-41. CrossRef Medline

Koob GF (1999) Stress, corticotropin-releasing factor, and drug addiction. Ann N Y Acad Sci 897:27-45. CrossRef Medline

Koya E, Uejima JL, Wihbey KA, Bossert JM, Hope BT, Shaham Y (2009) Role of ventral medial prefrontal cortex in incubation of cocaine craving. Neuropharmacology 56 [Suppl 1]:177-185. 
Kulis M, Queirós AC, Beekman R, Martín-Subero JI (2013) Intragenic DNA methylation in transcriptional regulation, normal differentiation and cancer. Biochim Biophys Acta 1829:1161-1174. CrossRef Medline

LaPlant Q, Vialou V, Covington HE 3rd, Dumitriu D, Feng J, Warren BL, Maze I, Dietz DM, Watts EL, Iñiguez SD, Koo JW, Mouzon E, Renthal W, Hollis F, Wang H, Noonan MA, Ren Y, Eisch AJ, Bolaños CA, Kabbaj M, et al. (2010) Dnmt3a regulates emotional behavior and spine plasticity in the nucleus accumbens. Nat Neurosci 13:1137-1143. CrossRef Medline

Lasek AW, Gesch J, Giorgetti F, Kharazia V, Heberlein U (2011) Alk is a transcriptional target of LMO4 and ERalpha that promotes cocaine sensitization and reward. J Neurosci 31:14134-14141. CrossRef Medline

Lattal KM, Wood MA (2013) Epigenetics and persistent memory: implications for reconsolidation and silent extinction beyond the zero. Nat Neurosci 16:124-129. CrossRef Medline

Lê AD, Harding S, Juzytsch W, Watchus J, Shalev U, Shaham Y (2000) The role of corticotrophin-releasing factor in stress-induced relapse to alcohol-seeking behavior in rats. Psychopharmacology 150:317-324. CrossRef Medline

Lee BR, Ma YY, Huang YH, Wang X, Otaka M, Ishikawa M, Neumann PA, Graziane NM, Brown TE, Suska A, Guo C, Lobo MK, Sesack SR, Wolf ME, Nestler EJ, Shaham Y, Schlüter OM, Dong Y (2013) Maturation of silent synapses in amygdala-accumbens projection contributes to incubation of cocaine craving. Nat Neurosci 16:1644-1651. CrossRef Medline

Li P, Wu P, Xin X, Fan YL, Wang GB, Wang F, Ma MY, Xue MM, Luo YX, Yang FD, Bao YP, Shi J, Sun HQ, Lu L (2014) Incubation of alcohol craving during abstinence in patients with alcohol dependence. Addict Biol. Advance online publication. Retrieved Apr 2, 2014. doi: 10.1111/ adb.12140. CrossRef Medline

Li X, DeJoseph MR, Urban JH, Bahi A, Dreyer JL, Meredith GE, Ford KA, Ferrario CR, Loweth JA, Wolf ME (2013) Different roles of BDNF in nucleus accumbens core versus shell during the incubation of cueinduced cocaine craving and its long-term maintenance. J Neurosci 33: 1130-1142. CrossRef Medline

Loweth JA, Tseng KY, Wolf ME (2014) Adaptations in AMPA receptor transmission in the nucleus accumbens contributing to incubation of cocaine craving. Neuropharmacology 76:287-300. CrossRef Medline

Lu L, Hope BT, Dempsey J, Liu SY, Bossert JM, Shaham Y (2005) Central amygdala ERK signaling pathway is critical to incubation of cocaine craving. Nat Neurosci 8:212-219. CrossRef Medline

Lu L, Uejima JL, Gray SM, Bossert JM, Shaham Y (2007) Systemic and central amygdala injections of the mGluR(2/3) agonist LY379268 attenuate the expression of incubation of cocaine craving. Biol Psychiatry 61:591598. CrossRef Medline

Lu L, Wang X, Wu P, Xu C, Zhao M, Morales M, Harvey BK, Hoffer BJ, Shaham Y (2009) Role of ventral tegmental area glial cell line-derived neurotrophic factor in incubation of cocaine craving. Biol Psychiatry 66: 137-145. CrossRef Medline

Madsen HB, Navaratnarajah S, Farrugia J, Djouma E, Ehrlich M, Mantamadiotis T, Van Deursen J, Lawrence AJ (2012) CREB1 and CREB-binding protein in striatal medium spiny neurons regulate behavioural responses to psychostimulants. Psychopharmacology 219:699-713. CrossRef Medline

Mameli M, Halbout B, Creton C, Engblom D, Parkitna JR, Spanagel R, Lüscher C (2009) Cocaine-evoked synaptic plasticity: persistence in the VTA triggers adaptations in the NAc. Nat Neurosci 12:1036-1041. CrossRef Medline

Maze I, Covington HE 3rd, Dietz DM, LaPlant Q, Renthal W, Russo SJ, Mechanic M, Mouzon E, Neve RL, Haggarty SJ, Ren Y, Sampath SC, Hurd YL, Greengard P, Tarakhovsky A, Schaefer A, Nestler EJ (2010) Essential role of the histone methyltransferase G9a in cocaine-induced plasticity. Science 327:213-216. CrossRef Medline

Meaney MJ, Szyf M (2005) Maternal care as a model for experiencedependent chromatin plasticity? Trends Neurosci 28:456-463. CrossRef Medline

Meijer L, Borgne A, Mulner O, Chong JP, Blow JJ, Inagaki N, Inagaki M, Delcros JG, Moulinoux JP (1997) Biochemical and cellular effects of roscovitine, a potent and selective inhibitor of the cyclin-dependent kinases cdc2, cdk2 and cdk5. Eur J Biochem 243:527-536. CrossRef Medline

Molloy PL, Watt F (1990) DNA methylation and specific protein-DNA interactions. Philos Trans R Soc Lond B Biol Sci 326:267-275. CrossRef Medline

Moussawi K, Kalivas PW (2010) Group II metabotropic glutamate recep- tors (mGlu2/3) in drug addiction. Eur J Pharmacol 639:115-122. CrossRef Medline

Nan X, Ng HH, Johnson CA, Laherty CD, Turner BM, Eisenman RN, Bird A (1998) Transcriptional repression by the methyl-CpG-binding protein MeCP2 involves a histone deacetylase complex [see comments]. Nature 393:386-389. CrossRef Medline

Nielsen DA, Huang W, Hamon SC, Maili L, Witkin BM, Fox RG, Cunningham KA, Moeller FG (2012) Forced abstinence from cocaine selfadministration is associated with DNA methylation changes in myelin genes in the corpus callosum: a preliminary study. Front Psychiatry 3:60. CrossRef Medline

Novikova SI, He F, Bai J, Cutrufello NJ, Lidow MS, Undieh AS (2008) Maternal cocaine administration in mice alters DNA methylation and gene expression in hippocampal neurons of neonatal and prepubertal offspring. PLoS One 3:e1919. CrossRef Medline

Pickens CL, Airavaara M, Theberge F, Fanous S, Hope BT, Shaham Y (2011) Neurobiology of the incubation of drug craving. Trends Neurosci 34:411420. CrossRef Medline

Razin A, Riggs AD (1980) DNA methylation and gene function. Science 210:604-610. CrossRef Medline

Renthal W, Maze I, Krishnan V, Covington HE 3rd, Xiao G, Kumar A, Russo SJ, Graham A, Tsankova N, Kippin TE, Kerstetter KA, Neve RL, Haggarty SJ, McKinsey TA, Bassel-Duby R, Olson EN, Nestler EJ (2007) Histone deacetylase 5 epigenetically controls behavioral adaptations to chronic emotional stimuli. Neuron 56:517-529. CrossRef Medline

Renthal W, Kumar A, Xiao G, Wilkinson M, Covington HE 3rd, Maze I, Sikder D, Robison AJ, LaPlant Q, Dietz DM, Russo SJ, Vialou V, Chakravarty S, Kodadek TJ, Stack A, Kabbaj M, Nestler EJ (2009) Genomewide analysis of chromatin regulation by cocaine reveals a role for sirtuins. Neuron 62:335-348. CrossRef Medline

Robison AJ, Nestler EJ (2011) Transcriptional and epigenetic mechanisms of addiction. Nat Rev Neurosci 12:623-637. CrossRef Medline

Scheyer AF, Wolf ME, Tseng KY (2014) A protein synthesis-dependent mechanism sustains calcium-permeable AMPA receptor transmission in nucleus accumbens synapses during withdrawal from cocaine selfadministration. J Neurosci 34:3095-3100. CrossRef Medline

Shukeir N, Pakneshan P, Chen G, Szyf M, Rabbani SA (2006) Alteration of the methylation status of tumor-promoting genes decreases prostate cancer cell invasiveness and tumorigenesis in vitro and in vivo. Cancer Res 66:9202-9210. CrossRef Medline

Sun J, Meyers MJ, Fink BE, Rajendran R, Katzenellenbogen JA, Katzenellenbogen BS (1999) Novel ligands that function as selective estrogens or antiestrogens for estrogen receptor-alpha or estrogen receptor-beta. Endocrinology 140:800-804. CrossRef Medline

Tate PH, Bird AP (1993) Effects of DNA methylation on DNA-binding proteins and gene expression. Curr Opin Genet Dev 3:226-231. CrossRef Medline

Thomassin H, Flavin M, Espinás ML, Grange T (2001) Glucocorticoidinduced DNA demethylation and gene memory during development. EMBO J 20:1974-1983. CrossRef Medline

Tian W, Zhao M, Li M, Song T, Zhang M, Quan L, Li S, Sun ZS (2012) Reversal of cocaine-conditioned place preference through methyl supplementation in mice: altering global DNA methylation in the prefrontal cortex. PLoS One 7:e33435. CrossRef Medline

Tropea TF, Kosofsky BE, Rajadhyaksha AM (2008) Enhanced CREB and DARPP-32 phosphorylation in the nucleus accumbens and CREB, ERK, and GluR1 phosphorylation in the dorsal hippocampus is associated with cocaine-conditioned place preference behavior. J Neurochem 106:1780 1790. CrossRef Medline

Uejima JL, Bossert JM, Poles GC, Lu L (2007) Systemic and central amygdala injections of the mGluR2/3 agonist LY379268 attenuate the expression of incubation of sucrose craving in rats. Behav Brain Res 181: 292-296. CrossRef Medline

Wang G, Shi J, Chen N, Xu L, Li J, Li P, Sun Y, Lu L (2013) Effects of length of abstinence on decision-making and craving in methamphetamine abusers. PLoS One 8:e68791. CrossRef Medline

Wolf ME, Tseng KY (2012) Calcium-permeable AMPA receptors in the VTA and nucleus accumbens after cocaine exposure: when, how, and why? Front Mol Neurosci 5:72. CrossRef Medline

Zovkic IB, Guzman-Karlsson MC, Sweatt JD (2013) Epigenetic regulation of memory formation and maintenance. Learn Mem 20:61-74. CrossRef Medline 